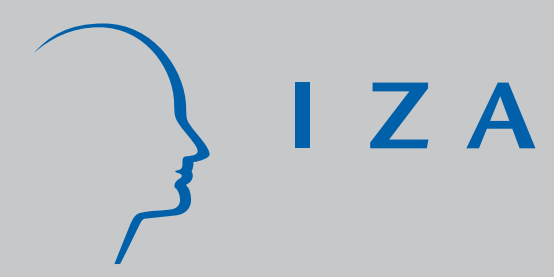

IZA DP No. 3990

Sentence Reductions and Recidivism:

Lessons from the Bastille Day Quasi Experiment

Eric Maurin

Aurelie Ouss

February 2009 


\title{
Sentence Reductions and Recidivism: Lessons from the Bastille Day Quasi Experiment
}

\author{
Eric Maurin \\ Paris School of Economics \\ and IZA
}

Aurelie Ouss

Paris School of Economics

\author{
Discussion Paper No. 3990 \\ February 2009
}

\author{
IZA \\ P.O. Box 7240 \\ 53072 Bonn \\ Germany \\ Phone: +49-228-3894-0 \\ Fax: +49-228-3894-180 \\ E-mail: iza@iza.org
}

\begin{abstract}
Any opinions expressed here are those of the author(s) and not those of IZA. Research published in this series may include views on policy, but the institute itself takes no institutional policy positions.

The Institute for the Study of Labor (IZA) in Bonn is a local and virtual international research center and a place of communication between science, politics and business. IZA is an independent nonprofit organization supported by Deutsche Post Foundation. The center is associated with the University of Bonn and offers a stimulating research environment through its international network, workshops and conferences, data service, project support, research visits and doctoral program. IZA engages in (i) original and internationally competitive research in all fields of labor economics, (ii) development of policy concepts, and (iii) dissemination of research results and concepts to the interested public.
\end{abstract}

IZA Discussion Papers often represent preliminary work and are circulated to encourage discussion. Citation of such a paper should account for its provisional character. A revised version may be available directly from the author. 
IZA Discussion Paper No. 3990

February 2009

\section{ABSTRACT \\ Sentence Reductions and Recidivism: Lessons from the Bastille Day Quasi Experiment}

This paper exploits the collective pardon granted to individuals incarcerated in French prisons on the $14^{\text {th }}$ of July, 1996 (Bastille Day) to identify the effect of collective sentence reductions on recidivism. The collective pardon generated a very significant discontinuity in the relationship between the number of weeks of sentence reduction granted to inmates and their prospective date of release. We show that the same discontinuity exists in the relationship between recidivism probability five years after the release and prospective date of release. Overall, the Bastille Day quasi experiment suggests that collective sentence reductions increase recidivism and do not represent a cost-effective way to reduce incarceration rates or prisons' overcrowding.

JEL Classification: K42

Keywords: crime, prison, deterrence effect, recidivism

Corresponding author:

Eric Maurin

Paris School of Economics

$48 \mathrm{Bd}$ Jourdan

75014 Paris

France

E-mail: Eric.maurin@ens.fr 


\section{Introduction}

More severe prison sanctions have plausibly a general deterrent effect on potential criminals, even on those who never served any prison sentence ${ }^{3}$. But longer prison sentences may also have an additional specific effect on the subsequent decisions of those who actually served them. Very little is known on this effect of the experience of prison, on the way longer terms in prison actually affect post-release behaviours ${ }^{4}$. Holding individual characteristics constant, does length of incarceration matter? Does it make a difference to be judged by more or less severe judges or to benefit from more or less generous sentence reductions?

Proponents of longer incarceration argue that the experience of prison deters individuals from recommitting new offences and that this 'specific deterrence' effect increases with incarceration length. It is also believed that a longer incarceration deteriorates prospects for subsequent illegitimate income by removing individuals from the influence of non-incarcerated criminals. Opponents argue that the experience of prison is dehumanizing, that it hardens individuals and makes reinsertion more difficult. They also argue that longer terms in prison favour interactions with incarcerated persons, which may increase individuals' criminal connections ${ }^{5}$. A longer spell in prison entails losses of potential experience in legitimate work, but makes it possible for the justice system to better prepare post-release periods, through training or rehabilitation programs ${ }^{6}$. All in all, longer incarcerations have

\footnotetext{
${ }^{3}$ See Gary Becker (1968), the recent surveys by Steven Levitt and Thomas Miles (2006) or Shawn Bushways and Peter Reuter (2008), the recent contributions by David Lee and Justin McCrary (2005), Eric Helland and Alexander Tabarok (2007) or Daniel Kessler and Levitt (1999).

${ }^{4}$ An early conceptualization of the difference between the general deterrence effect of punishment (punishment as a threat) and the specific deterrence effect (the influence of the memory of past punishment) is provided by Glueck (1928). For a sociological contribution, see Smith and Gartin (1989).

${ }^{5}$ For recent evidence on prison as a "school of crime", see Patrick Bayer, Randi Hjalmarsson and David Pozen, 2008.

${ }^{6}$ In France, the law stipulates that the mission of the penitentiary administration is not only to keep prisoners under supervision, but also to prepare their social reinsertion.
} 
ambiguous effects on the attractiveness of both illegitimate and legitimate activities after release and it is an empirical question to identify their net effect on recidivism.

To address this issue, we ideally would like to compare otherwise similar inmates who have not served the same term in prison. One basic problem is that most sentence reductions granted by the penitentiary administration depend on individuals' behaviour and characteristics. Holding original crime and sentence constant, inmates who obtain the largest sentence reductions (and serve the shortest terms) are typically those with the lowest recidivism risks. In such a case, the comparison of recidivism rates across inmates who served different terms for a given crime does not provide a credible evaluation of the causal effect of time actually served in prison on recidivism.

To overcome this problem, this paper exploits the French collective pardon granted to inmates in July 1996, just before the Bastille Day (14 ${ }^{\text {th }}$ of July, 1996). As discussed below, individuals who were in French prisons by Bastille Day benefited from a basic sentence reduction of one week, plus one additional week of reduction per residual month of sentence by Bastille Day, with total reduction not exceeding 4 months. By construction, this collective pardon generated a very significant discontinuity in the relationship between time served in prison and prospective date of release ${ }^{7}$. Inmates whose prospective date of release lies just after Bastille Day served on average a significantly shorter sentence than those whose prospective date of release was just before Bastille Day and who were by construction not eligible to the pardon. Interestingly enough, we find that a similar discontinuity exists in the relationship between recidivism rate and prospective date of release: five years after the release, the rate of recidivism of inmates whose prospective date of release is just after the Bastille Day is about 12 percent points larger than the rate of recidivism of those released just before the Bastille Day. Overall, the discontinuous increase in collective sentence reduction

\footnotetext{
${ }^{7}$ For example, an individual incarcerated the $1^{\text {st }}$ of June 1996 with prospective date of release $1^{\text {st }}$ of July 1996 benefits from zero week of sentence reduction whereas an individual incarcerated $15^{\text {st }}$ of June 1996 with prospective date of release $15^{\text {st }}$ of July benefits from one week of sentence reduction.
} 
observed at the Bastille Day cut-off coincides with a discontinuous increase in recidivism. The corresponding regression-discontinuity estimate suggests that each additional percentage point in collective remission rate generates about one additional point of recidivism rate five years after the release.

We develop a second identification strategy, building on the non-monotone, discontinuous relationship between the number of weeks of collective remissions granted to inmates and the residual sentence by Bastille Day. Focusing on the sub-population of inmates released after the Bastille Day and holding prospective date of release constant, the proportion of the original sentence served in prison first increases as date of incarceration becomes closer to the Bastille Day (because of the increase in the proportion of residual sentence by Bastille Day) and then falls abruptly to zero just after the Bastille Day (because of eligibility loss). Again, we find that the same non-monotone, discontinuous, relationship exists between recidivism rate and date of incarceration, with a significant negative shift taking place just at the Bastille Day cut-off. The corresponding instrumental variable estimate provides us with an evaluation of the effect of collective remission on recidivism which is as significant, and of the same order of magnitude, as our initial regression-discontinuity estimate.

The key features of the French Presidential Pardon is that eligibility does not depend on individual characteristics, but varies discontinuously when prospective date of release or date of incarceration increases from just before to just after the Bastille Day. These institutional features make it possible to compare otherwise similar inmates who are granted significantly different sentence reductions. This comparison suggests that collective sentence reductions increase recidivism rates. This policy represents a plausibly less effective way to reduce incarceration rates and prisons' overcrowding than alternative strategies previously analysed in the literature, such as sentence suspensions or individual sentence reductions, 
maybe because these alternative strategies preserve a more direct relationships between sanctions and individual behaviours.

The paper is organized as follows: the next section provides an overlook of the related literature. Section 2 describes French institutions and the data available. Section 3 provides an evaluation of the effect of collective remission on recidivism using the discontinuity in the relationship between prospective date of release and Presidential Pardon. Section 4 provides an alternative evaluation using the non monotone, discontinuous relationships between the date of incarceration and the number of weeks of collective remission for inmates released after the Bastille day. Section 5 provides a discussion of our results and the last section concludes.

\section{Related literature}

There is a large body of studies analysing the statistical relationships between time served in prison and recidivism (see e.g. the meta-analysis by Paula Smith, Claire Goggin and Paul 2002), but most of these papers rely on simple OLS estimates and the corresponding evaluations mix the true effect of incarceration length and a selection bias (i.e., inmates who served longer terms are those with the highest potential of recidivism). In contrast, there exist very few evaluations relying on variations in incarceration length that are plausibly exogenous to recidivism potential.

In a recent contribution, Ilyana Kuziemko (2007) exploits the mass release of prisoners that took place in the US, in the state of Georgia, in the early eighties. On March $18^{\text {th }}$, 1981 , the governor of Georgia ordered the release of 900 inmates to reduce overcrowding in local jails. A selection of non-violent inmates were ranked by day of prospective release and the 900 closest to release were let out. Holding original sentence constant, the only reason for 
variation in sentence reductions across the inmates from this list was variation in date of incarceration. Kuziemko (2007) finds nevertheless that those who benefited from longer sentence reduction had significantly higher recidivism rate after the release. Assuming that date of incarceration is exogenous to recidivism, this result is consistent with longer incarceration having a negative effect on the recidivism rate of the least violent inmates. As noted by Kuziemko (2007), there are several reasons why this effect may not generalize to average prisoner. First, the immediate release surprised prisoners and those receiving the largest breaks may have been the least prepared for the release. Also, only a specific selection of offenders were released.

In a related paper, Jeffrey Kling (2006) compares the labour market outcomes of otherwise similar individuals who have shorter or longer prison sentences because their cases were randomly assigned to more or less severe judges. He finds no significant differences in earnings and employment probabilities across judges. Assuming that judges’ severity affects subsequent outcomes only insofar as it affects incarceration length, this strategy suggests that incarceration length has no significant effect on inmates' subsequent labour market outcomes.

Randi Hjalmarsson (2008) exploits discontinuities in punishment that arise in Washington juvenile sentencing guideline to analyse the effect of incarceration on postrelease behaviour. She finds that incarceration reduces the probability of being reconvicted of a crime. Francesco Drago, Roberto Galbiati and Pietro Vertova (2008) use the Collective Clemency Bill passed by Italian parliament in 2006 to identify whether sentence suspension has an effect on recidivism. Upon the approval of the Bill, a population of 22,000 inmates was released from Italian prison, but the Bill states that if a former inmate recommits a crime within five years following the release, he will be required to serve the residual sentence suspended by the pardon on top of the new sentence. They find that the commutation of one additional month of actual sentence into one additional month of suspended sentence reduces 
significantly the propensity to recommit a crime. This natural experiment captures the joint effect of the reduction of actual time spent in prison and of the corresponding increase in expected sanctions. Lawrence Katz, Steven Levitt and Ellen Shushtorovitch (2003) analyse variation in prison death across states and year, and find that this indicator of prison condition is negatively correlated with crime rates. This result is consistent with poor prison conditions deterring criminals either through lower recidivism (specific deterrence) or through general deterrence, if poor prison conditions are well known within the population of potential criminals. Chen and Shapiro (2004) exploit a discontinuity in the assignment of federal prisoners to security levels to show that harsher prison conditions (i.e., higher security level) do not lead to less recidivism. All in all, there is still little evidence on the causal effect of the experience of prison on post-release behaviours. To the best of our knowledge, the Bastille Day experiment considered in this paper is the first to provide an evaluation of the influence on an average prisoner of reductions in incarceration length that are proportional to residual sentences.

\section{Institutional Context and Data Description}

Between 1990 and 2006, a collective pardon was granted to incarcerated persons each year, in early July, by the President of the French Republic ${ }^{8}$. Specifically, a collective pardon act (decret de grace) was emitted by the President a couple of days before the Bastille Day (French national day, $14^{\text {th }}$ of July) granting sentence reductions that were approximately proportional to the residual sentence by the date of the act. In 1996, the pardon act is emitted the $9^{\text {th }}$ of July and reduces residual sentences by one week, plus one additional week per

\footnotetext{
${ }^{8}$ President Sarkozy has not used this right in 2007 after his election and the right of collective pardon has been removed from French constitutional law in 2008.
} 
residual month of sentence by the date of the act, with a limit of 4 months of overall sentence reduction. A copy of the 1996 act is provided in Appendix.

Whereas everything in a sentence and its execution is related to individual circumstances, almost everyone in prison is eligible to the Bastille Day pardon and to the corresponding sentence reductions. The only exceptions correspond to a small given list of types of crimes (terrorism, crimes against children, crimes against the administration of prison, see Appendix). Individual characteristics and circumstances, such as good behaviour in prison, crime history or reinsertion opportunities, are not taken into account and have no effect on eligibility. For the vast majority of crimes, the only determinant of eligibility is whether individuals are in prison by the date of the pardon act, that is whether they have been incarcerated before the Bastille Day and whether their prospective date of release is after the Bastille Day. This paper builds on each of these two institutional features to provide evaluations of the effect of collective remissions on subsequent recidivism rates.

\section{II.1 Data and variables}

The dataset corresponds to a sample of about 3,000 prison releases representative of those that took place in France between the beginning of May 1996 and the end of May 1997. For each observation, we have information on the exact date of release $\left(t_{r}\right)$, the exact date of incarceration $\left(t_{i}\right)$ as well as the original sentence length (denoted $D_{m}$ ). The actual length of time spent in prison is $D=t_{r}-t_{i}$ and the ratio $T=\left(D-D_{m}\right) / D_{m}$ represents the overall remission rate i.e., the proportion of the original sentence which has not been spent in prison. For example, $T$ is equal to $1 / 3$ for a person originally sentenced to 6 months of prison and who benefited from 2 months of remission. 
With respect to recidivism, we have information on whether individuals were re-arrested before May 2002 as well as the exact date of re-arrest. Hence, it is possible to construct for inmates in our sample a dummy $Y$ indicating whether the inmate has been re-arrested during the 5 years following the release. The overall recidivism rate after 5 years is about $45 \%$ in our dataset (see some basic statistics in Appendix, Table A1).

With respect to collective remissions, we know whether inmates benefited from a Presidential Pardon in the past, either in 1996 or before, as well as the total number of weeks of collective remissions $c$. The ratio $C=c /(D+c)$ represents what we call the collective remission rate, i.e., the rate of reduction of the incarceration length which has been specifically generated by collective remissions.

Note that if $I=\left(D_{m}-(D+c)\right) / D_{m}$ denotes the individual remission rate (the reduction of the original sentence generated by all the non-collective remissions), we have the basic relationships between overall, collective and individual remissions :

$$
(1-T) \equiv(1-I)(1-C)
$$

The presidential pardon generates an increase in $C$ and one important issue will be whether it is transmitted directly to $T$ or whether the effect is mitigated by a decrease in individual remissions, as measured by $I$.

With respect to regulations, the two basic determinants of the collective remission rate are whether the inmate is still in Prison by $t_{c}=1996$, July the 9th and - for inmates still in prison by $t_{c}$ - the fraction of the sentence that potentially remained to be spent in prison by $t_{c}$. Denoting $t_{s}$ the prospective date of release that would have been observed in the absence of the 1996 pardon, the first institutional determinant corresponds to the dummy variable $1\left(t_{s}>\right.$ $t_{c}$ ) whereas the second one corresponds to the ratio $f=\left(t_{s}-t_{c}\right) /\left(t_{s}-t_{i}\right)$ (for inmates such that $\left(t_{s}>\right.$ $\left.t_{c}\right)$ ). For persons released before the $t_{c}$ cut-off or incarcerated after $t_{c}, t_{s}$ is equal to the actual date of release $t_{r}$. For persons incarcerated before $t_{c}$ and released after $t_{c}$, we can set 
$t_{s}=t_{r}+7\left(c_{s}+1\right)$ where $c_{s}$ represents the number of periods of three weeks that have been actually spent in prison after $t_{c}$. Given official regulations, each additional three-week period spent in prison actually corresponds to an additional month that should have been spent in prison minus an additional week of collective remissions. Given that our dataset provides a representative sample of releases for any $t_{r}$ lying between May 1996 and May 1997, it also makes it possible to construct representative sample of prospective release for any $t_{s}$ lying between the same dates ${ }^{9}$.

III. The Effect of Collective Remission on Recidivism: A RegressionDiscontinuity Evaluation

As discussed above, the first basic necessary condition in order to be eligible to the 1996 presidential pardon is to still be in prison by the $9^{\text {th }}$ of July, $1996=t_{c}$. Inmates whose date of release is just before the $t_{c}$ cut-off are not eligible to the 1996 pardon. Their date of release would have been the same in the absence of the 1996 presidential pardon. In contrast, the vast majority of those whose date of release is after the cut-off have actually benefited from the 1996 pardon and the corresponding collective remissions. Their actual date of release occurs after the $t_{c}$ cut-off, but before the date that would have been observed in the absence of the 1996 pardon. To explore the relationship between remissions and recidivism, we are first going to build on this regulation and compare the outcomes of otherwise similar inmates who differ with respect to whether their prospective date of release took place just before or just after the $t_{c}$ cut-off. Put differently, our first identifying strategy uses the fact that Pardon

\footnotetext{
${ }^{9}$ By construction, for any prospective $t_{s}$ lying between May 1996 and May 1997, the corresponding $t_{r}$ also lies between May 1996 and May 1997 and is actually represented in our dataset. Hence, our dataset makes it possible to construct sub-sample of releases representative of those satisfying $t_{1} \leq t_{s} \leq t_{2}$, for any $t_{1}$ and $t_{2}$ comprised between 1996, May,1 and 1997, May, 31.
} 
regulations generate a discontinuity in the relationship between $t_{s}$ and the probability of pardon probability at the $t_{c}$ cut-off.

\section{III.1 Graphical Analysis}

To begin with, Figures 1a to $1 \mathrm{~d}$ focus on the sample representative of male inmates whose prospective dates of release $t_{s}$ lie between May and September 1996 (i.e., about 2 months before and after $t_{c}$ ) and show the variation in the probability of pardon and in the different rates of remission across fortnights of prospective release $\left(t_{s}\right)$.

Comfortingly, Figure 1a confirms that pardon regulations generate a very significant discontinuity in the relationship between the prospective date of release $t_{s}$ and the probability of pardon. We find a 70 percentage points increase in the probability of benefiting from presidential pardon when prospective date of release $t_{s}$ moves from just below to just above the $t_{c}$ cut-off. The collective remission rate $(C)$ increases from less than $3 \%$ before the cut-off ${ }^{10}$ to above $10 \%$ after the cut-off (Figure $1 \mathrm{~b}$ ). French institutions actually generate a very sharp increase in probability of pardon and collective remissions just after the $t_{c}$ cut-off. In contrast, there is no evidence of a significant shift in rates of individual remissions after the cut-off (Figure 1c). It is around 25\% just before and just after the cut-off. This result confirms that collective remissions are not used as substitute for ordinary individual remissions and contribute to an actual increase in the overall remission rate. Figure 1d further confirms that the shift in Pardon probability and collective remissions is actually accompanied by a very clear increase in the overall remission rate after the cut-off. The overall remission rate is about $26 \%$ for dates of release just before $t_{c}$ and jumps above $32 \%$ for date of release just above $t_{c}$.

\footnotetext{
${ }^{10} \mathrm{C}$ is not zero before $t_{c}$ because of the inmates who benefited from previous Bastille Day pardons (i.e., granted in July of year 1995 or before) and who were still in prison by May 1996. Note that our dataset does not provide information on the exact year when the different weeks of collective remission have been granted. We only have information on the total number of weeks of pardon.
} 
Given these findings, one important issue is whether the shift in remission coincides with a change in the nature of the crimes committed. Interestingly enough, we do not find any discontinuous shift in the type of jurisdiction and procedure involved ${ }^{11}$ (Figure 2a). There is actually no discontinuous change the type of crimes committed. For example, the proportion of thefts and receiving remains very close to $25 \%$ before and after the cut-off (Figure $2 \mathrm{~b}$ ). Also, we do not find any significant variation in the number of releases per fortnight before and after the cut-off (Figure 2c). Most importantly, Figure 2d does not show any significant shift in original sentence $D_{m}$ just after the cut-off. We observe a smooth decline in original sentence length before the summer period (between early May and early July), but no discontinuity at the cut-off. The original sentence length is about exactly the same (near 500 days) before and after the cut-off. Overall, the results in Fig. 2a-2d are consistent with the assumption that the nature and number of original sentences are very similar for inmates released just before or just after $t_{c}$. The existence of the pardon does not seem to affect the behaviour of potential criminal, nor the severity of judges.

Within this context, the next key question is whether we observe a significant change in the probability of recidivism after the cut-off. Interestingly enough, Figure 3 shows that the increase in remission rate just after the cut-off is accompanied by an unambiguous increase in recidivism rate. There is a smooth decline in recidivism before the cut-off - which coincides with the decline in original sentence length observed in Fig. $2 b$ - but when we compare inmates released just before and just after the cut-off, we observe a jump of about 10 percent points in recidivism. This pattern is consistent with the assumption that a reduction in time spent in prison due to collective remissions actually increases recidivism probability.

\footnotetext{
${ }^{11}$ There is a procedure correctionnelle for relatively minor crimes and a procedure criminelle for major ones.
} 


\section{III.2 Regression Analysis}

Table 1 goes beyond simple visual evidence and provides regression-discontinuity estimates of the effect of presidential pardon on the probability of recidivism. Panel A uses the full sample (i.e., the sample representative of male inmates whose prospective date of release lies between May 1996 and May 1997) and provide estimates of the discontinuity in inmates' outcomes at the $t_{c}$ cut-off. Specifically, the first model shows the regression of a dummy indicating presidential pardon on dummy indicating whether the prospective date of release $\left(t_{s}\right)$ takes place after the cut-off date $t_{c}$, holding a spline function of $t_{s}$ constant (i.e., holding $t_{s}$ and $\left(t_{s}-t_{c}\right) \times 1\left(t_{s}>t_{c}\right)$ constant). We also use a full set of 13 original sentence dummies as control variables. The regression confirms that there is a huge discontinuity in the probability of presidential pardon at the cut-off (about -67.2 percentage points). In contrast, the second model confirms that there is no significant discontinuity in original sentence at the cut-off date. Using the same specification, Table A2 in Appendix further shows that there is no discontinuity in the nature of the crime committed by persons released before and after the cut-off. Also we find no age discontinuity, no discontinuity in the proportion of single person and no discontinuity in the proportion of homeless at the cut-off.

If we denote $Y_{1 i}$ the potential recidivism of inmate $i$ if he benefits from presidential pardon and $Y_{0 i}$ the potential recidivism if he does not benefit from the pardon, the continuity of the length of the original sentence at the cut-off date is consistent with the assumption that the basic determinants of potential recidivism as well as the potential recidivism rates themselves are continuous at the cut-off. Under this maintained assumption, the ratio of the discontinuity in recidivism and the discontinuity in pardon provides an estimate of the causal effect $\mathrm{E}\left(Y_{1}-Y_{0}\right.$ $\left./ t_{s}-t_{c}\right)$ at the cut-off release date $t_{c}$ (see Hahn, Todd and Van Der Klaw, 2001). 
The third model shows that the discontinuity in recidivism is actually positive (which suggests a positive impact of pardon on recidivism) and statistically significant at standard level. Model (5) shows the corresponding regression-discontinuity estimate of the causal effect of pardon on recidivism and confirms that it is positive and significant at standard level. It is not significantly different from the OLS estimate given by model 4 , however. The RD estimate suggests that presidential pardon yields an increase of about 18 percent points in the probability of recidivism five years after the release.

Panel B of Table 1 tests whether these results are robust when we restrict the sample to prospective dates of release just above and after the cut-off. Specifically, it shows the regression results for the sub-sample of sentences with prospective release dates between May and September 1996 (i.e., two months before and after the cut-off). Generally speaking, the two first models confirm that there exist a very significant discontinuity in the probability of pardon at the cut-off date and that this discontinuity does not coincide with a discontinuity in original sentence. Also, the reduced form and IV estimates obtained with the restricted sample are very similar to those obtained with the full sample and provide us with a very similar evaluation of the causal effect of Pardon on recidivism.

The presidential Pardon increases collective remissions and this is the simplest explanation for its effect on recidivism. Using the same specification as in Table 1, the first model of Table 2 confirms that there is a very significant discontinuity in collective remission rates at the cut-off $(+12.5$ percent points). The shift in remission rates is actually of about the same order of magnitude as the shift in recidivism rate. Assuming that pardon affects recidivism only through collective remissions, these findings suggest that the elasticity of recidivism rate to collective remission rate is close to 1 . This is confirmed by the regression-discontinuity evaluation of the effect of collective remission rates on recidivism rate (model 3, Table 2). 
By focusing on the discontinuity at the 1996 Bastille Day cut-off, our regression-discontinuity estimate isolates the effect of the pardon granted in 1996 on eligible inmates. It is a mix between the effect of the 1996 Pardon on inmates incarcerated after the 1995 Bastille Day (and who benefited from the 1996 Pardon only) and the effect of the 1996 Pardon on inmates incarcerated before the 1995 Bastille Day (and who may have benefited from other Pardons). Table A3 in Appendix provides separate analysis for the two sub-samples. The estimates obtained with the sub-sample incarcerated after the 1995 Bastille Day are very similar to those obtained with the full sample. The effects obtained with the sub-sample incarcerated before the 1995 Bastille Day are much less well estimated, due to the small size of the subsample ( $\mathrm{n}=472)$. We observe positive shifts in collective remission and recidivism rates after the cut-off in this sub-sample too, but the effects are marginally significant only. Overall, the data do not make it possible to evaluate how exactly the marginal effect of an additional pardon on individuals incarcerated before the 1995 Bastille Day compares with the effect of benefiting from just one Pardon on those incarcerated after the 1995 Bastille Day.

IV. The Effect of Collective Remission on Recidivism: Alternative Evaluation

Until now, we have only used one potential source of identification of the effect of collective remissions on recidivism, which is the discontinuous increase in collective remissions when prospective date of release $t_{s}$ moves from just below to just above the $t_{c}$ cut-off. In this section we are going to use a completely different feature of official regulations, which is the relationship between the number of weeks of collective remission generated by the 1996 pardon and the residual sentence length at the $t_{c}$ cut-off.

To be specific, consider an inmate whose prospective date of release $t_{s}$ takes place after the Bastille Day cut-off. If his date of incarceration $t_{i}$ takes place before Bastille Day, the 1996 
pardon generates a number of weeks of collective remission which is about one quarter of $\left(t_{s^{-}}\right.$ $t_{c}$ ) the residual duration of incarceration by $t_{c}$ (one additional week of remission for each remaining month). The ratio $f=\left(t_{s}-t_{c}\right) /\left(t_{s}-t_{i}\right)$ coincides with the fraction of the sentence that remains to be spent in prison by $t_{c}$ and the 1996 pardon generates an increase in the rate of collective remission $C$ that is approximately proportional to $f$. In contrast, if the date of incarceration took place after the $t_{c}$ cut-off (i.e., $f>1$ ), then the 1996 pardon generates no additional week of collective remission and has no effect on $C$.

Overall, focusing on individuals released after $t_{c}$ and holding prospective date of release $t_{s}$ constant, the collective remission rate generated by the 1996 presidential pardon should first increase with date of incarceration $t_{i}$, as $t_{i}$ grows closer to the $t_{c}$ cut-off and as the ratio $f=\left(t_{s^{-}}\right.$ $\left.t_{c}\right) /\left(t_{\mathrm{s}}-t_{i}\right)$ comes closer to the $f=1$ cut-off. Secondly, the collective remissions generated by the 1996 pardon should fall abruptly as incarceration date $t_{i}$ moves from before to after the $t_{c}$ cutoff and as the ratio $f=\left(t_{\mathrm{s}}-t_{c}\right) /\left(t_{\mathrm{s}}-t_{i}\right)$ increases from just below to just above the $f=1$ cut-off. In other words, holding $t_{s}>t_{c}$ constant, regulations should imply first an increase in the collective remission rate $C$ with respect to the fraction of the sentence that remained to be spent in prison by the $t_{c}$ cut-off, followed by a discontinuous decrease at the $f=1$ cut-off and by a flat relationship between $C$ and $f$ after the cut-off.

To test whether this pattern is actually observed in the data, Figures $4 \mathrm{a}$ to $4 \mathrm{c}$ focus on the sample $\mathrm{e}^{12}$ of inmates whose prospective dates of release $t_{s}$ lie approximately in the middle of our post-pardon period (i.e., between November, 1996 and 2007, January) and provide an analysis of the variation in their collective remission rates, their recidivism rate and their original sentence when $f$ increases from below to above the $f=1$ cut-off. To draw these graphs, we use a discrete measure of $f$ with four values before $f=1$ and four values above $f=1$,

\footnotetext{
${ }^{12}$ The small fraction of individuals who have been incarcerated after the Bastille Day and who nevertheless benefited from the Pardon because they had been judged beforehand are dropped from the sample under consideration. The graphical patterns are very similar when we keep these observations.
} 
corresponding to the quartiles of the distribution of $f$ below and above 1 . Figure 4a confirms that the collective remission rates first increase as $f$ get closer to 1 (and as the fraction of the sentence that remains to be spent in prison by $t_{c}$ increases) and fall abruptly after the cut-off. This pattern is perfectly consistent with the official regulations of the Pardon. Also, Figure 4b confirms that original sentence decreases continuously and monotonically as $f$ increases from below to above 1 . This is consistent with the very definition of $f$, which is inversely proportional to original sentence for any fixed value of $t_{s}$. Within this context, the question is whether recidivism varies in the same non-monotonic, discontinuous way as collective pardon or whether it varies in the same continuous, monotonic way as original sentence. Most interestingly, Figure 4c shows that recidivism first increases continuously as $f$ gets closer to 1 , but undergoes the same negative shift as collective pardon at the the $f=1$ cutoff. This pattern is obviously consistent with collective pardon having a negative effect on recidivism.

Table 3 goes beyond graphical evidence and provides a regression analysis where we use the residual sentence at the cutoff as an instrumental variable. To begin with, Model 1 of Table 3 focuses on inmates released after the $t_{c}$ cut-off (i.e., $t_{s}>t_{c}$ ) and shows the regression of the collective remission rate $C$ on a spline function of $f=\left(t_{s}-t_{c}\right) /\left(t_{s}-t_{i}\right)$ with a knot at $f=1$, holding $t_{s}$ constant. It amounts regressing $C$ on the fraction of the sentence that remains to be spent in prison by $t_{c}$ (as measured by the interaction $f x(f<1)$ ) and on a dummy indicating that incarceration takes place just after $t_{c}$ (as measured by the dummy variable $1(f \geq 1)$ ), using prospective date of release $t_{s}$ and the ratio $f$ as a control variables. The regression confirms that $C$ first increases significantly with the fraction of the sentence that remains to be spent in prison (as measured by the significant and positive effect of $f(f<1)$ ) then undergoes a significant drop at the $f=1$ cut-off (as measured by the significant negative effect of $(f<1)$ ) and 
finally remains stable after the cut-off (as shown by the non-significant main effect of $f$ ). As noted above, this pattern is highly consistent with official regulations.

Given this fact, the question is whether we observe the same specific relationship between recidivism and $f$ as between remission and $f$. Most interestingly, Model 2 in Table 3 confirms that this is the case. Focusing on inmates satisfying $\left(t_{s}>t_{c}\right)$, the recidivism rate first increase with the fraction that remains to be spent in prison, then undergoes a negative shift at the $f=1$ cut-off and finally remains flat when the ratio $f$ becomes larger than 1 . In substance, we observe the same highly non-linear, discontinuous, relationship between date of incarceration and recidivism as between date of incarceration and collective remissions. The third column provides the results of an Instrumental Variable evaluation of the effect of collective remission on recidivism using the fraction of the sentence that remains to be spent in prison as an instrumental variable (i.e., $f x(f<1)$ ) whereas the fourth column shows the results when we use jointly the fraction of the sentence that remains to be spent in prison and the dummy indicating that date of incarceration is above the cut-off as instrumental variables. Interestingly enough, both strategies provide a similar evaluation of the effect of collective remission on recidivism and this evaluation is itself very close to the evaluation obtained in the first part of the paper using the discontinuity in the relation between $t_{s}$ and remission as source of identification. Overall, the different approaches suggest that collective remission increases significantly the probability of recidivism, each additional point of collective remission being followed by an additional point of recidivism five years after the release.

\section{Discussion}

Incarceration rates are increasing dramatically in France as in many other western countries. French incarceration rate is about 97/100,000 in 2007 whereas it was about 
70/100,000 in 1985. More people are spending longer periods of time in French prisons than ever before, even though the French incarceration rate remains much lower than the American one. This penal policy has entailed important increases in the amount of money spent on prisons by tax payers, at the detriment of other governmental functions. In France, the cost of prison is about 2,000 euros per month and incarcerated individual, so that the increase in the number of inmates over the twenty last years represents an additional cost of about 400 millions euros per year. For the sake of comparison, it is of the same order of magnitude as the budget devoted to educational priority zones, created in France in the early eighties and routinely criticized for being too cosmetic.

Also, prisons' capacity is not growing as rapidly as the number of incarcerated individuals, so that overcrowding is increasing and prison conditions are worsening dramatically. The estimated capacity of French prison is about 50,000 whereas the number of incarcerated persons is about 65,000 , which yields an overcrowding rate of about $130 \%$. The suicide rate in French prisons is one the highest observed in the western world. It is about 24/10,000, which is twice more than in the eighties and much larger than in the US (about 16/10000).

Within this context, the issue of finding alternatives to prison is very high on the political agenda, in France as in many other western countries. This paper suggests that collective remissions - i.e., remissions that are not related to individual characteristics or behaviours - increase recidivism and may not be the most cost-effective option. Consider for example a sentence reduction of $10 \%$ granted to all French inmates (i.e., an average reduction of about one month granted to 65,000 prisoners). On the one hand, it would reduce current prison costs by about 130 millions euros $(2,000 \times 65,000)$. On the other hand, it would increase subsequent prison costs by about the same amount since it would increase the probability of re-incarceration five years after the release by about the same proportion of 10 
percentage points. Given that recidivism leads in general to longer prison terms, we can even speculate that this policy would increase prison costs in the long run. We would also observe a $10 \%$ increase in the number of re-arrests five years after the release, that is a minimum of about 6,500 additional crimes $(65,000 \times 10 \%)$. It is obviously very difficult to evaluate the social and economic costs of such an increase in crimes. Recent rough evaluations ${ }^{13}$ suggest that the social cost of crime is about 25 billions euros per year in France. Assuming that only one third of this cost corresponds to recidivism, we can evaluate that the cost of the increase in crime rates would alone be as large as initial decrease in prison costs.

Overall, even if it is very difficult to provide a precise evaluation, a collective decrease in incarceration length seems clearly not cost-effective. It seems much more effective to reduce incarceration length through sentence suspension, as in the Italian case analysed by Drago et al. (2008). Sentence suspension has the same positive short-term effect on incarceration rate and prison overcrowding, but it also reduces recidivism through increasing the general deterrence effect for ex-inmates. From a different viewpoint, Farrington and Welsh (2005) provide a careful survey of existing randomized experiments on crime and justice which reveal that some preventive methods and court-mandated therapies are actually effective in reducing reoffending. Unfortunately, most of this literature has been conducted in the US and little is known on the effect of these alternatives to prison in other societies.

\section{Conclusion}

This paper contributes to the literature on the effect of the experience of prison on inmates’ subsequent behaviour. Specifically, we use the collective pardon granted to French inmates on 1996 Bastille Day, to identify the effect of collective sentence reductions on

\footnotetext{
${ }^{13}$ See Jean-Philippe Arlaud (2006). A recent evaluation by the British Home Office provides us with a much larger evaluation of about 60 billions pounds for England and Wales (Sam Brand and Richard Price, 2000).
} 
recidivism five years after the release. The pardon created a significant discontinuity in the relationships between incarceration length and prospective date of release at the Bastille Day cut-off. Also, holding prospective date of release constant, it generates discontinuous variations in the number of week of collective remissions granted to inmates across dates of incarceration. Most interestingly we show that the same discontinuities exist in the distribution of recidivism rates across inmates, which suggests a significant causal effect of collective sentence reductions on recidivism.

As it turns out, sentence reductions granted on a collective basis seem to attenuate the deterrence effect of experience of prison on ex-inmates. This result stands in contrast with previous research (such as Kling, 2006) showing that individual variation in time served has essentially no effect on subsequent outcomes. It is the collective nature of the Bastille Day pardon which is plausibly problematic. Inmates who receive large collective remissions may form the impression that there is no direct relationships between ones' individual behaviour and sanctions and thus be less deterred after their release.

The quasi experiment used in this paper provides estimates of the average effect of collective sentence reductions. An open question is whether the effect is the same across the different groups of inmates. For example, it would be interesting to know whether the effect is as large for short and long sentences. It would make it possible a better targeting of sentence reduction policies. The sample used in this paper is not large enough to address this issue. Another important question is whether the experience of prison affects the nature of recidivism, on top of its frequency. The next step on our research agenda is to collect larger dataset with more detailed information on post-release behaviours in order to shed light on these issues. 
References :

Arlaud, Jean-Philippe, 2006, Délinquance et insécurité : combien ça vous coûte ?, Edition Publibook.

Barbarino, Alessandro and Giovani Mastrobuoni, 2008, The Incapacitation Effect of Incarceration: Evidence from Several Italian Collective Pardons, Unpublished Manuscript.

Bayer, Patrick, Randi Hjalmarsson and David Pozen, 2008, Building Criminal Capital Behind Bars: Peer Effects in Juvenile Corrections, Quarterly Journal of Economics, forthcoming.

Becker, Garry, 1968, Crime and Punishment: An Economic Approach, Journal of Political Economy, vol: 76(2), 169-217.

Brand, Sam and Richard Price, 2000, The Economic and Social Cost of Crime, Home Office Research Study n²17, London.

Bushway, Shawn and Peter Reuter, 2008, Economists' Contribution of the Study of Crime and the Criminal Justice System, Crime and Justice: A Review of Research, 37:389-451.

Chen, M. Keith and Jess M. Shapiro, 2007, Do Harsher Prison Conditions Reduce Recidivism? A Discontinuity-based Approach, American Law and Economics Review.

Drago Francesco, Roberto Galbiati and Pietro Verova, 2008, The Deterrent Effects of Prison: Evidence from a Natural Experiment, IZA discussion paper 3395.

Farrington David P. and Brendan C. Welsh, 2006, Half Century of Randomized Experiments on Crime and Justice, Crime and Justice: A Review of Research, vol: 34 pp:34-55.

Glueck, Sheldon, 1928, Principles of a Rational Penal Code, Harvard Law Review, vol:41 (4) 453-482.

Hahn, J., P. Todd and W. Van Der Klaw, 2001, Identification and Estimation of Treatment Effects with a Regression Discontinuity Design, Econometrica, vol: 69 (1), pp:201-209.

Helland Eric and Alexander Tabarok, 2007, Does Three Strikes Deter? A Non Parametric Estimation, Journal of Human Resources, XLII (2): 309-330.

Kessler Daniel P. and Steven D. Levitt, 1999, "Using Sentence Enhancements to Distinguish Between Deterrence and Incapacitation”, Journal of Law and Economics, 17 (1):343-363.

Katz, Lawrence, Steven D. Levitt and Ellen Shustorovitch, 2003, Prison Conditions, Capital Punishment and Deterrence, American Law and Economics Review, vol: 5(2), pp:318-343.

Kling, Jeffrey, Incarceration Length, Employment and Earnings, 2006, American Economic Review 96(3) pp: 863-876.

Kuziemko Ilyana, 2007, Going Off Parole; How the Elimination of Discretionary Prison Release Affects the Social Costs of Crime, NBER Working Paper, 13380. 
Lee, David S. and Justin McCrary, 2005, Crime, Punishment and Myopia, Unpublished Manuscript.

Levitt, Steven D. and Thomas Miles, 2006, Economic Contribution to the Understanding of Crime, Annual Review of Law and Social Science. December 2006, Vol.2: pp.147-164.

Levitt, Steven D. and Daniel Kessler, Using Sentence Enhancements to Distinguish between Deterrence and Incapacitation, Journal of Law and Economics, 1999, 42, pp. 343-63.

Pintoff, Randi, 2008, Juvenile Jails: A Path to the Straight and Narrow or Hardened Criminality? Journal of Law and Economics, forthcoming.

Smith D. A. and Gartin P. R. (1989), Specifying specific deterrence: the influence of arrest on future criminal activity, American Sociological Review, vol: 54: 94-105.

Smith Paula, Claire Goggin Paul Gendreau, 2002, The Effects of Prison Sentences and Intermediate Sanctions on Recidivism: Age, Gender and Race, Ottawa, Ontario; Solicitor General of Canada, Corrections Research Branch 
Figure 1a : Probability of Presidential Pardon, Before and After $t_{c}=1996$, July the $9^{\text {th }}$.

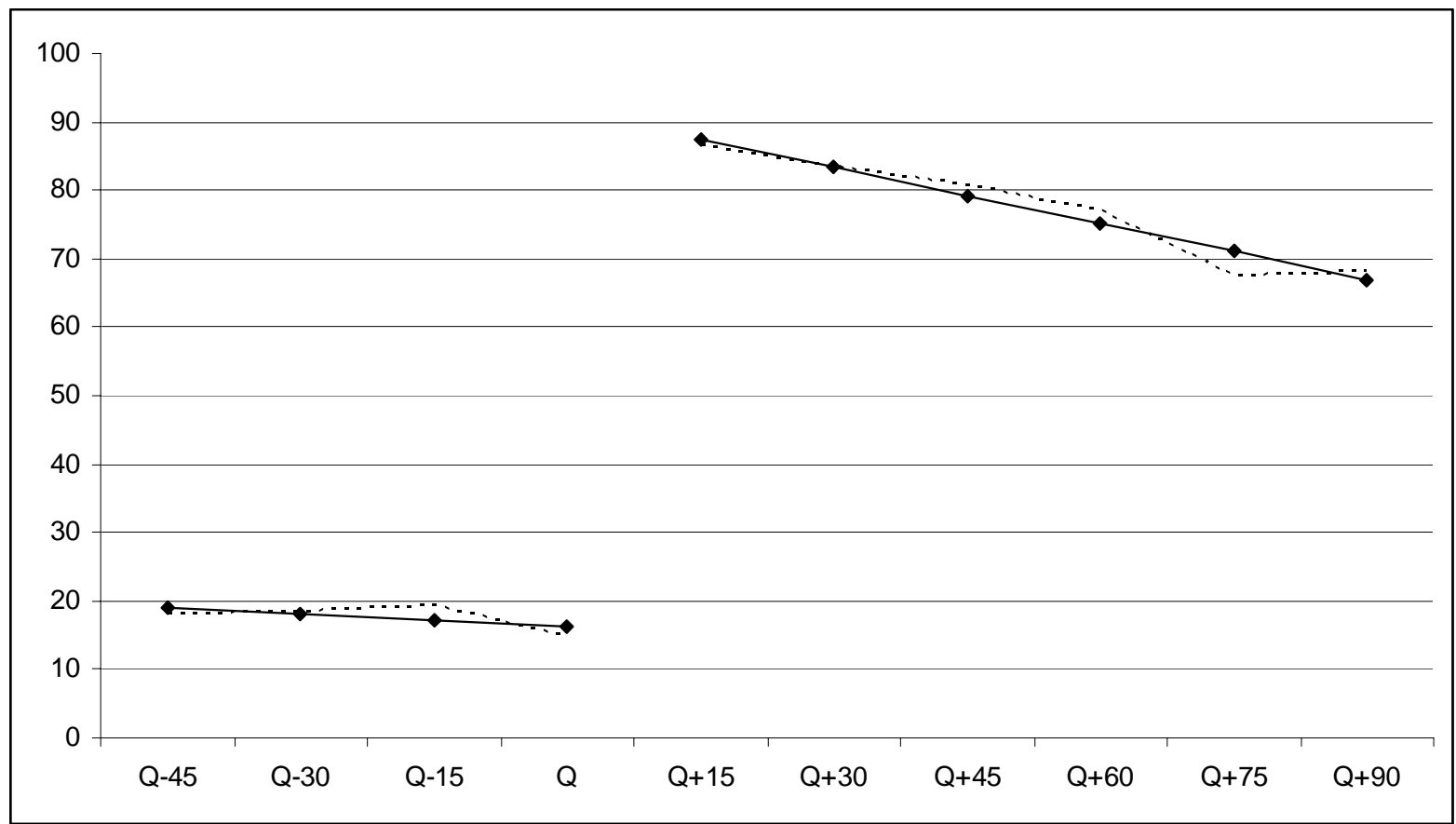

Sample: Male, prospective date of release $t_{s}$ comprised between 4 fortnights before $t_{c}=1996$, July the $9^{\text {th }}$ (i.e., Q45) and 6 fortnights after $t_{c}(\mathrm{Q}+90)$.

Figure 1b: Collective Remission Rate $(C)$ Before and After $t_{c}=1996$, July the $9^{\text {th }}$.

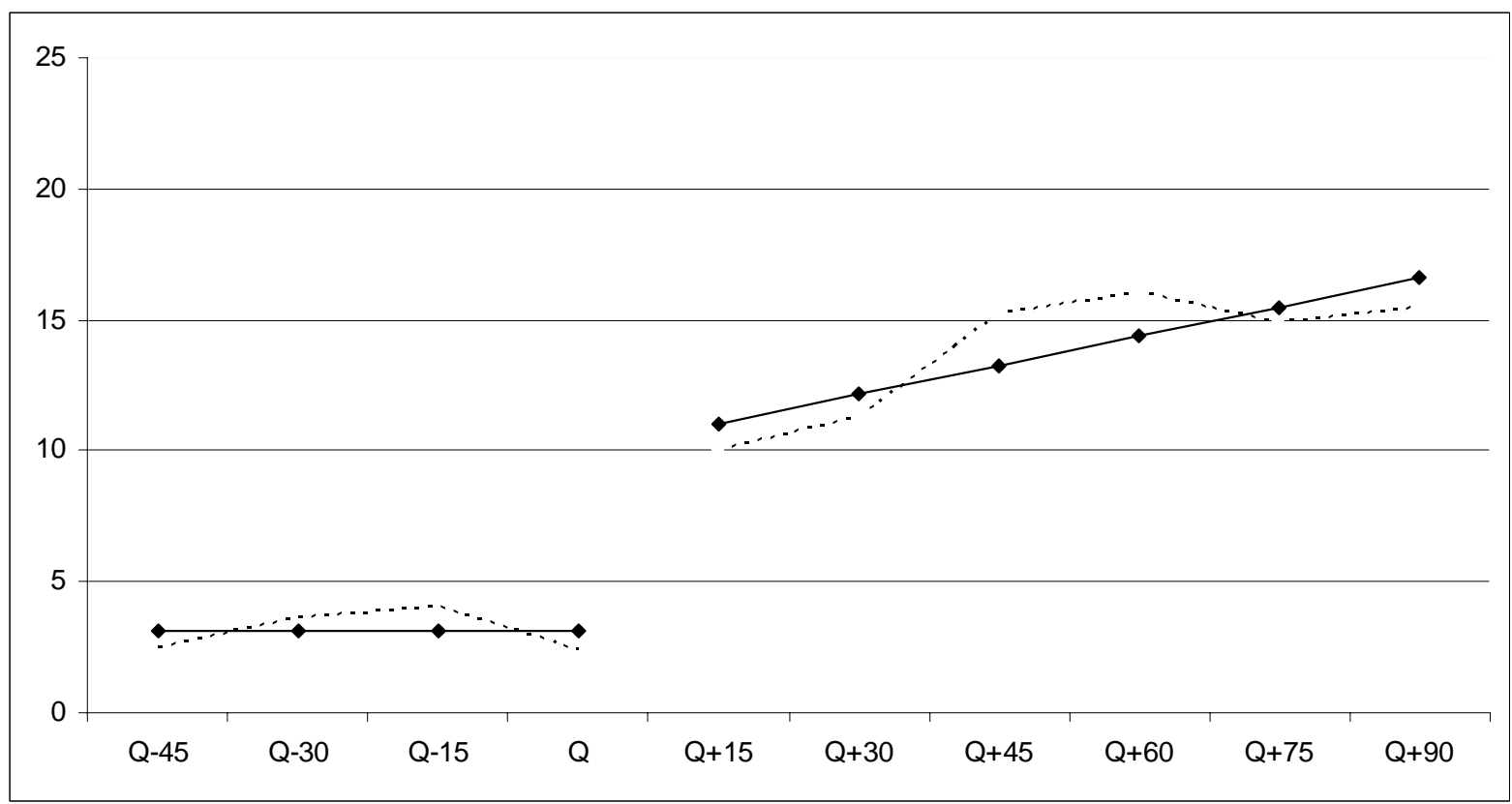

Sample: Male, prospective date of release $t_{s}$ comprised between 4 fortnights before $t_{c}=1996$, July the $9^{\text {th }}$ (i.e., Q$45)$ and 6 fortnights after $t_{c}(\mathrm{Q}+90)$. 
Figure 1c: Rate of Individual Remissions $(I)$, Before and After $t_{c}=1996$, July the $9^{\text {th }}$.

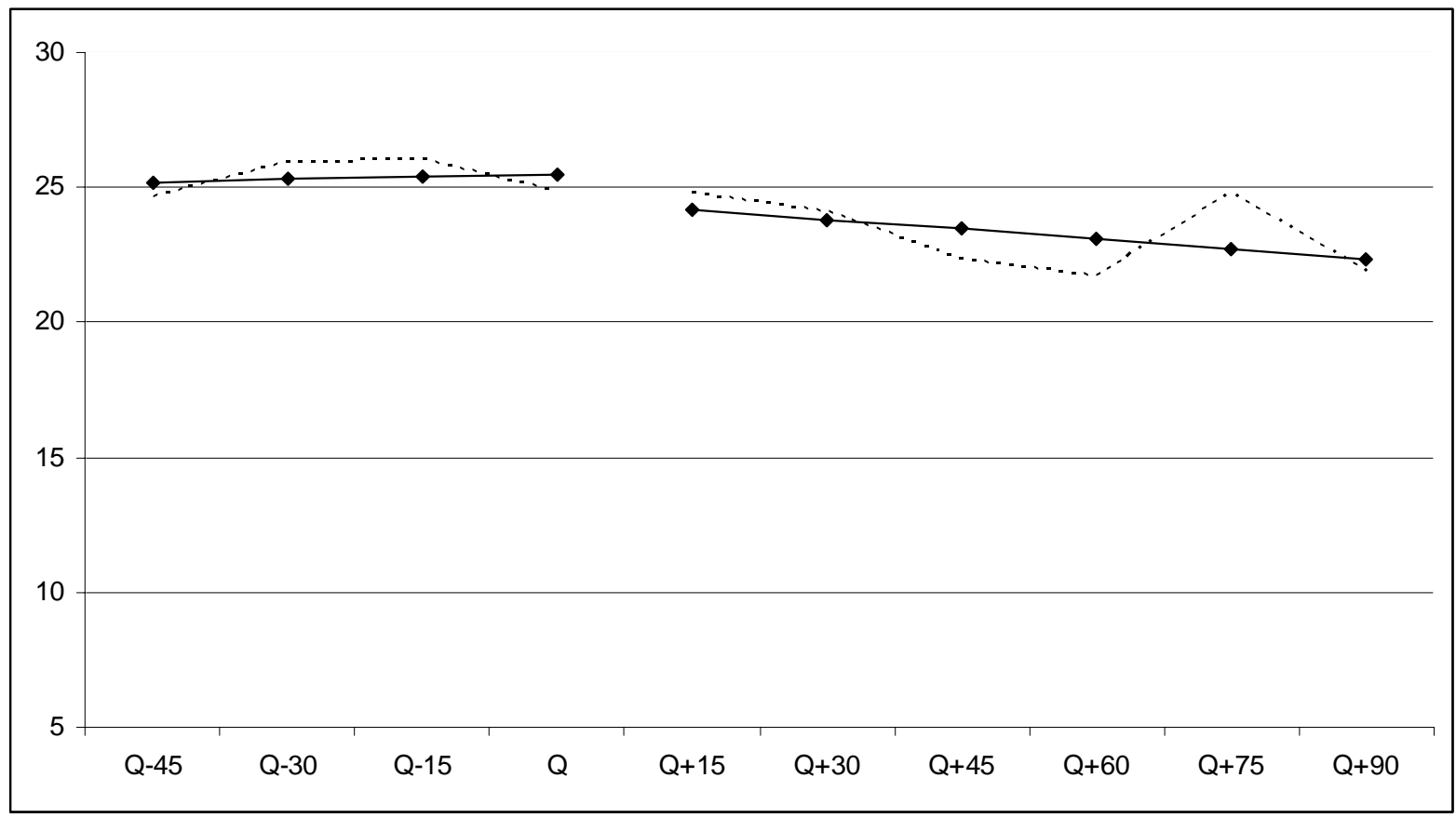

Sample: Male, prospective date of release $t_{s}$ comprised between 4 fortnights before $t_{c}=1996$, July the $9^{\text {th }}$ (i.e., Q45) and 6 fortnights after $t_{c}(\mathrm{Q}+90)$.

Figure 1d: Overall Remission Rate $(T)$, Before and After $t_{c}=1996$, July the $9^{\text {th }}$.

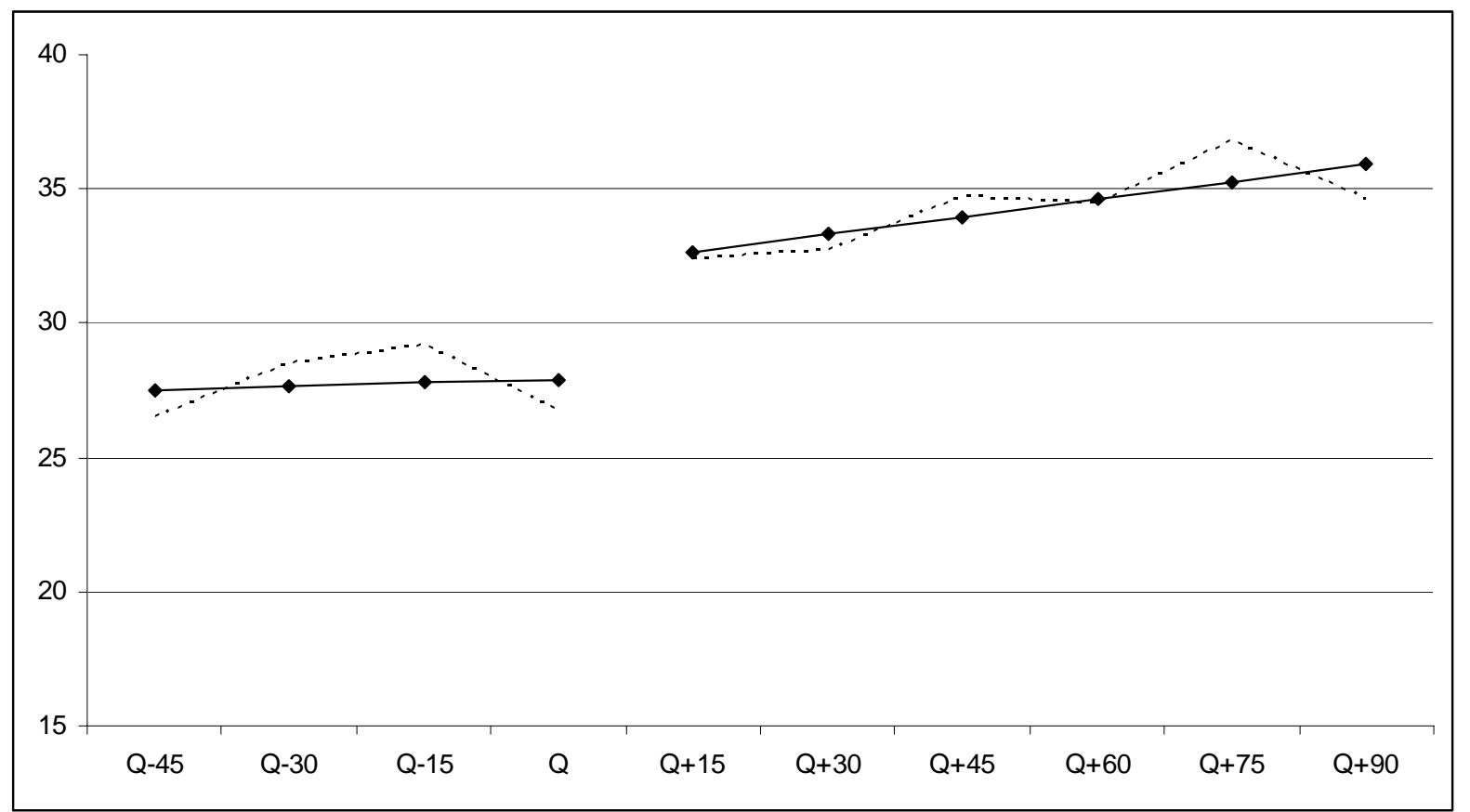

Sample: Male, prospective date of release $t_{s}$ comprised between 4 fortnights before $t_{c}=1996$, July the $9^{\text {th }}$ (i.e., Q$45)$ and 6 fortnights after $t_{c}(\mathrm{Q}+90)$. 
Figure 2a: Proportion of Procedure Correctionnelle Cases, Before and After $t_{c}=1996$, July the $9^{\text {th }}$.

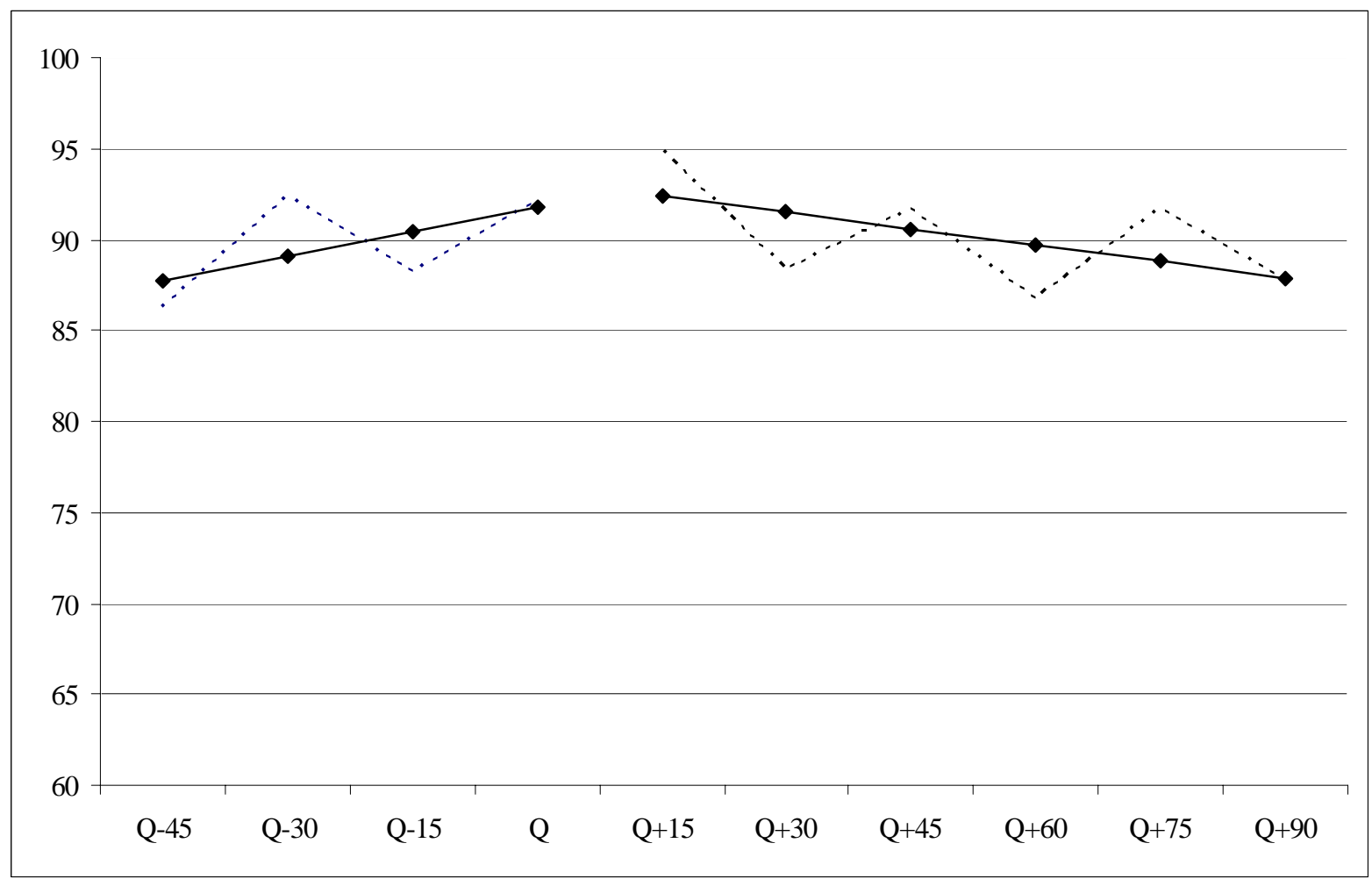

Sample: Male, prospective date of release $t_{s}$ comprised between 4 fortnights before $t_{c}=1996$, July the $9^{\text {th }}$ (i.e., Q45) and 6 fortnights after $t_{c}(\mathrm{Q}+90)$.

Figure 2b: Proportion of thefts and receiving, Before and After $t_{c}=1996$, July the $9^{\text {th }}$ cut-off.

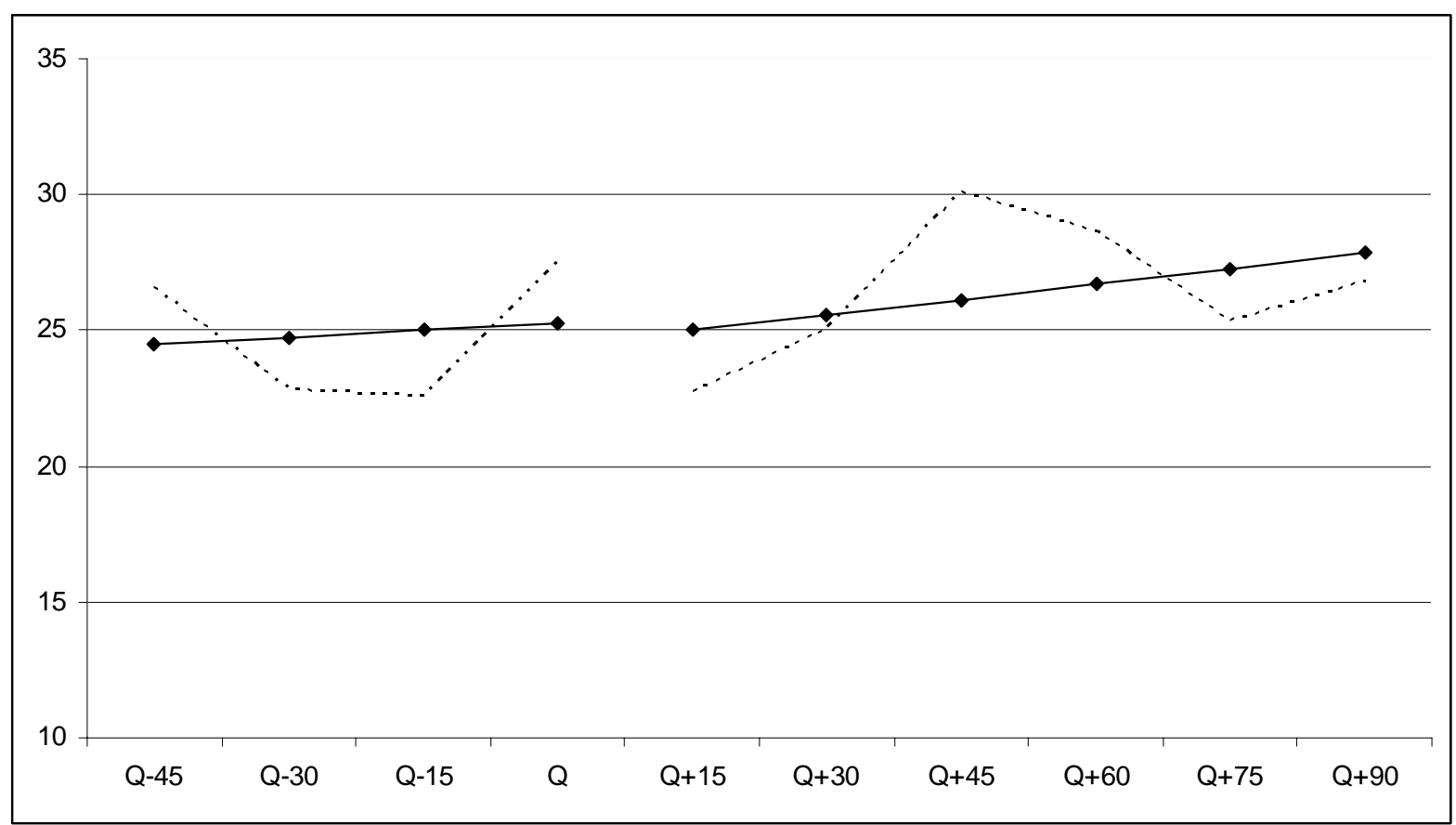

Sample: Male, prospective date of release $t_{s}$ comprised between 4 fortnights before $t_{c}=1996$, July the $9^{\text {th }}$ (i.e., Q45) and 6 fortnights after $t_{c}(\mathrm{Q}+90)$. 
Figure 2c: Number of Releases per Fortnight, Before and After $t_{c}=1996$, July the $9^{\text {th }}$.

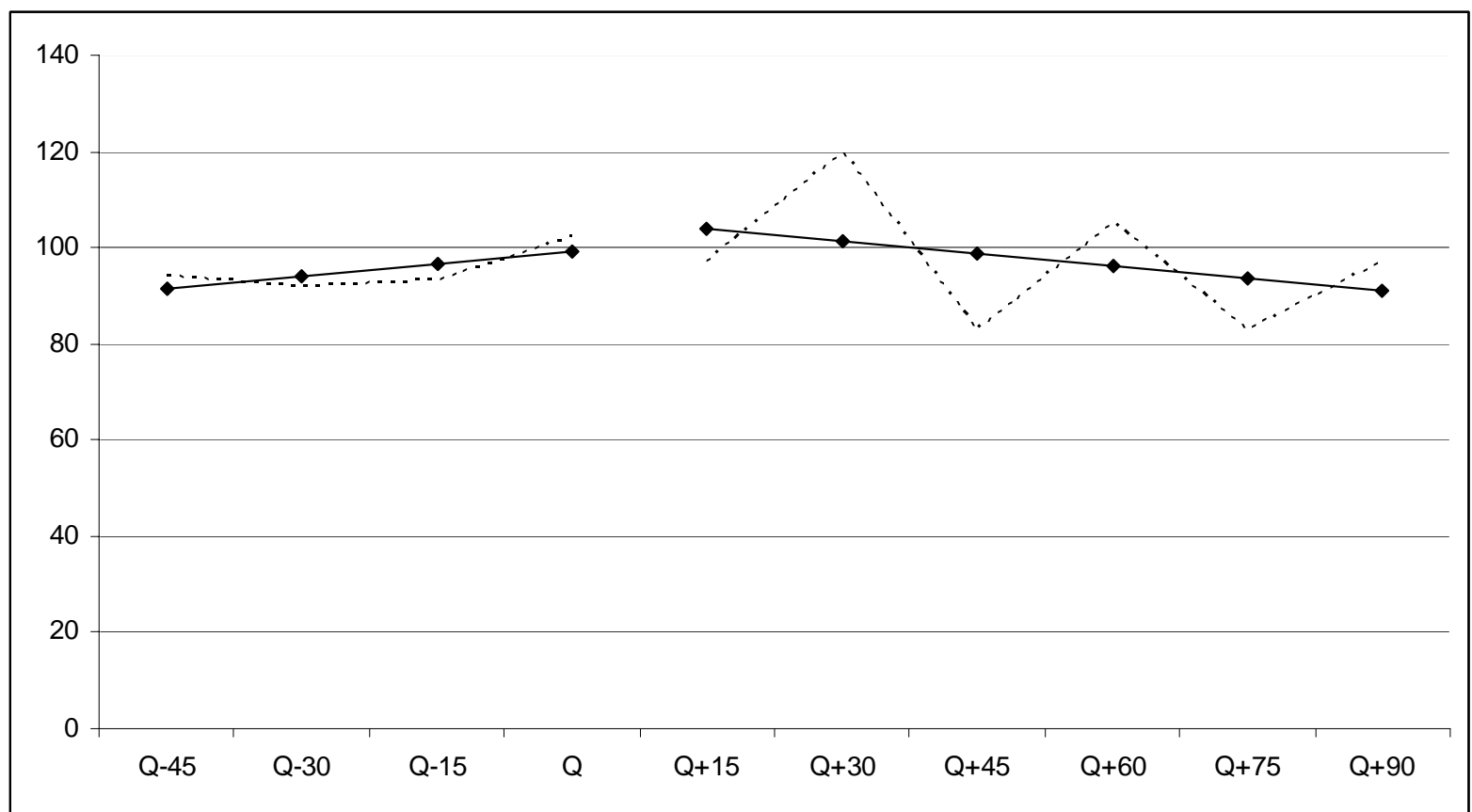

Sample: Male, prospective date of release $t_{s}$ comprised between 4 fortnights before $t_{c}=1996$, July the $9^{\text {th }}$ (i.e., Q45) and 6 fortnights after $t_{c}(\mathrm{Q}+90)$.

Figure 2d: Original Sentence Length $\left(D_{m}\right.$, in days), Before and After $t_{c}=1996$, July the $9^{\text {th }}$.

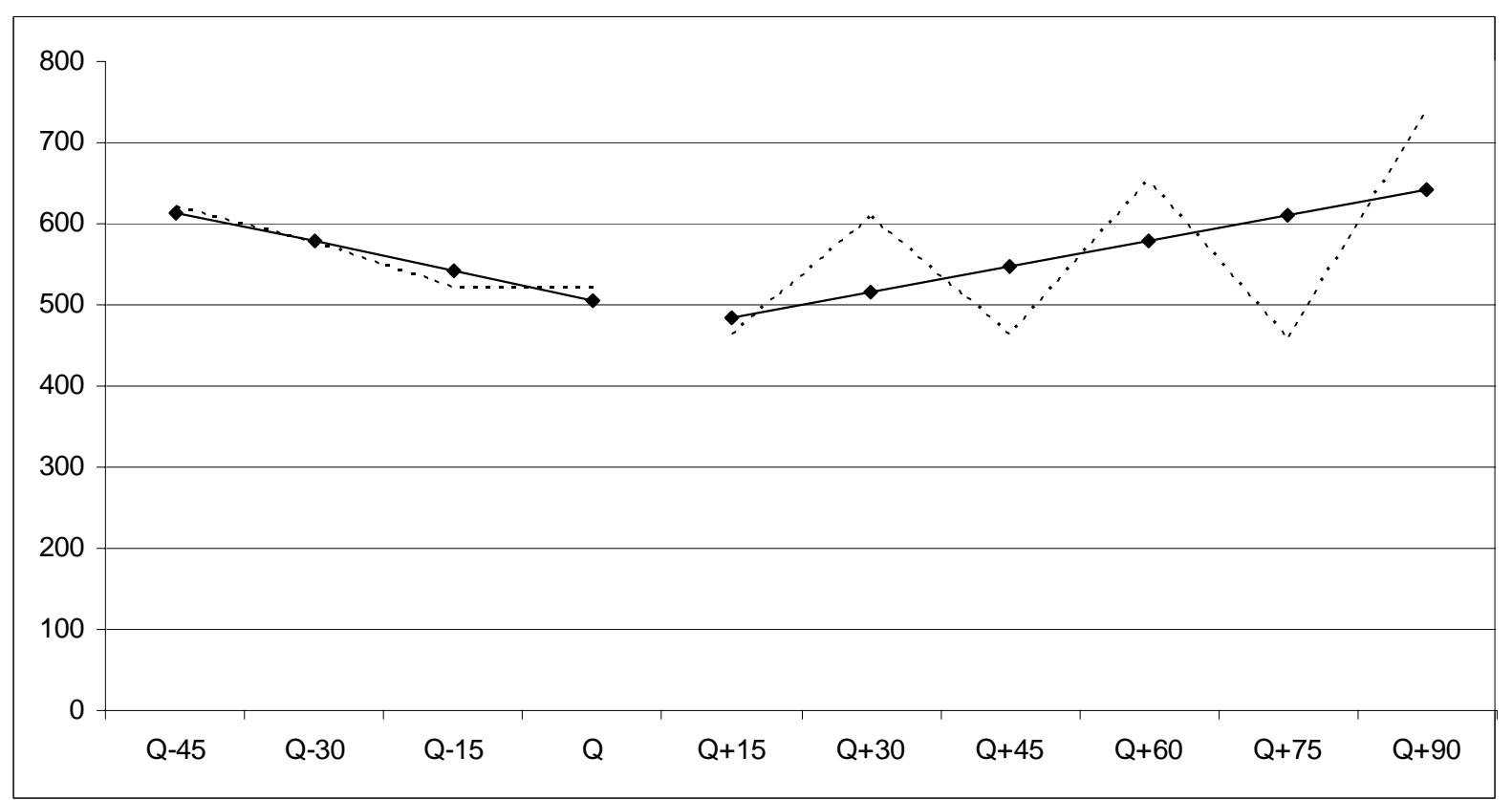

Sample: Male, prospective date of release $t_{s}$ comprised between 4 fortnights before $t_{c}=1996$, July the $9^{\text {th }}$ (i.e., Q$45)$ and 6 fortnights after $t_{c}(\mathrm{Q}+90)$. 
Figure 3: Probability of Recidivism, Before and After $t_{c}=1996$, July the $9^{\text {th }}$.

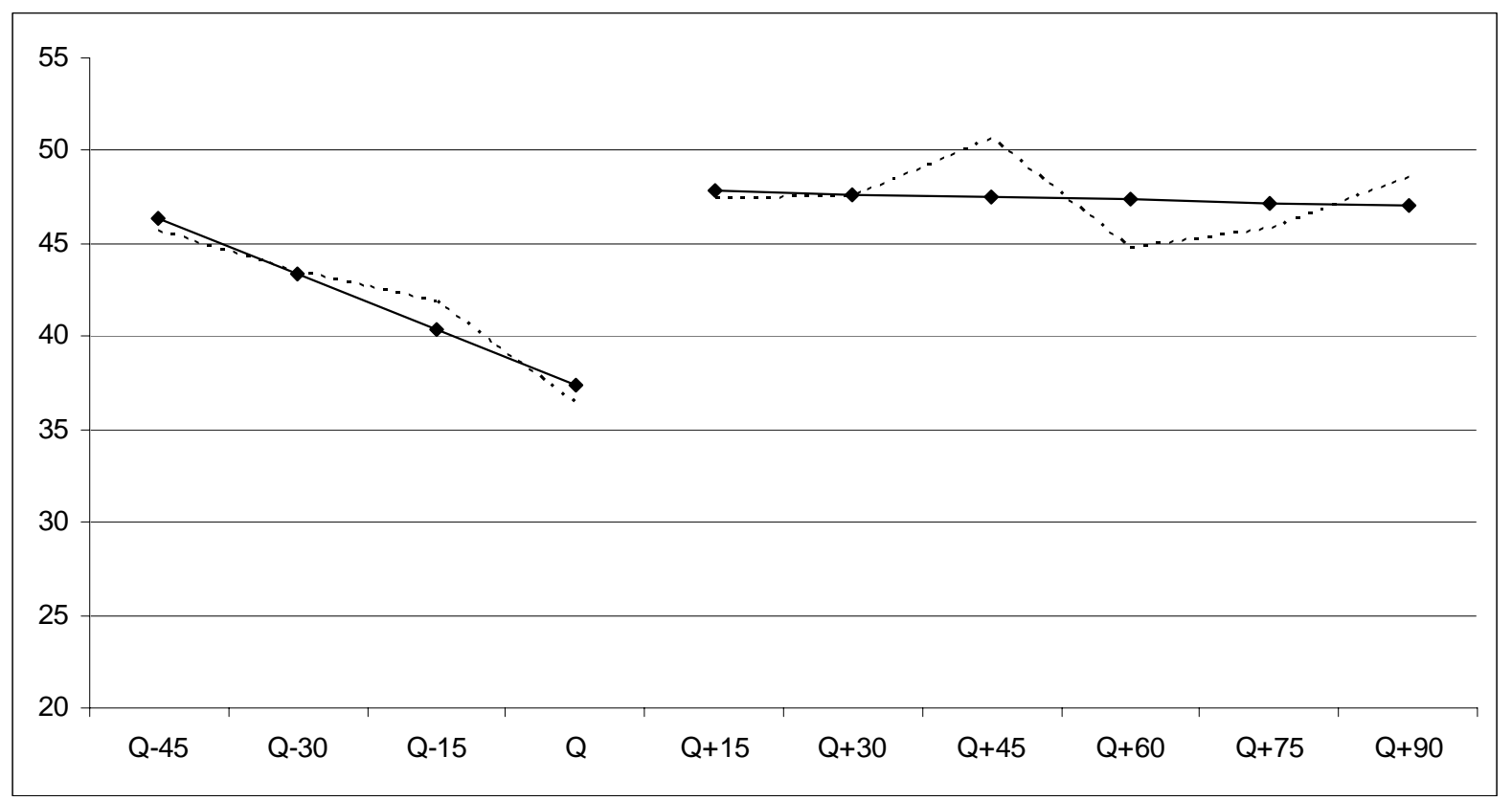

Sample: Male, prospective date of release $t_{s}$ comprised between 4 fortnights before $t_{c}=1996$, July the $9^{\text {th }}$ (i.e., Q45) and 6 fortnights after $t_{c}(\mathrm{Q}+90)$. 
Figure 4a : Collective Remission Rate as a Function the Residual Sentence Ratio.

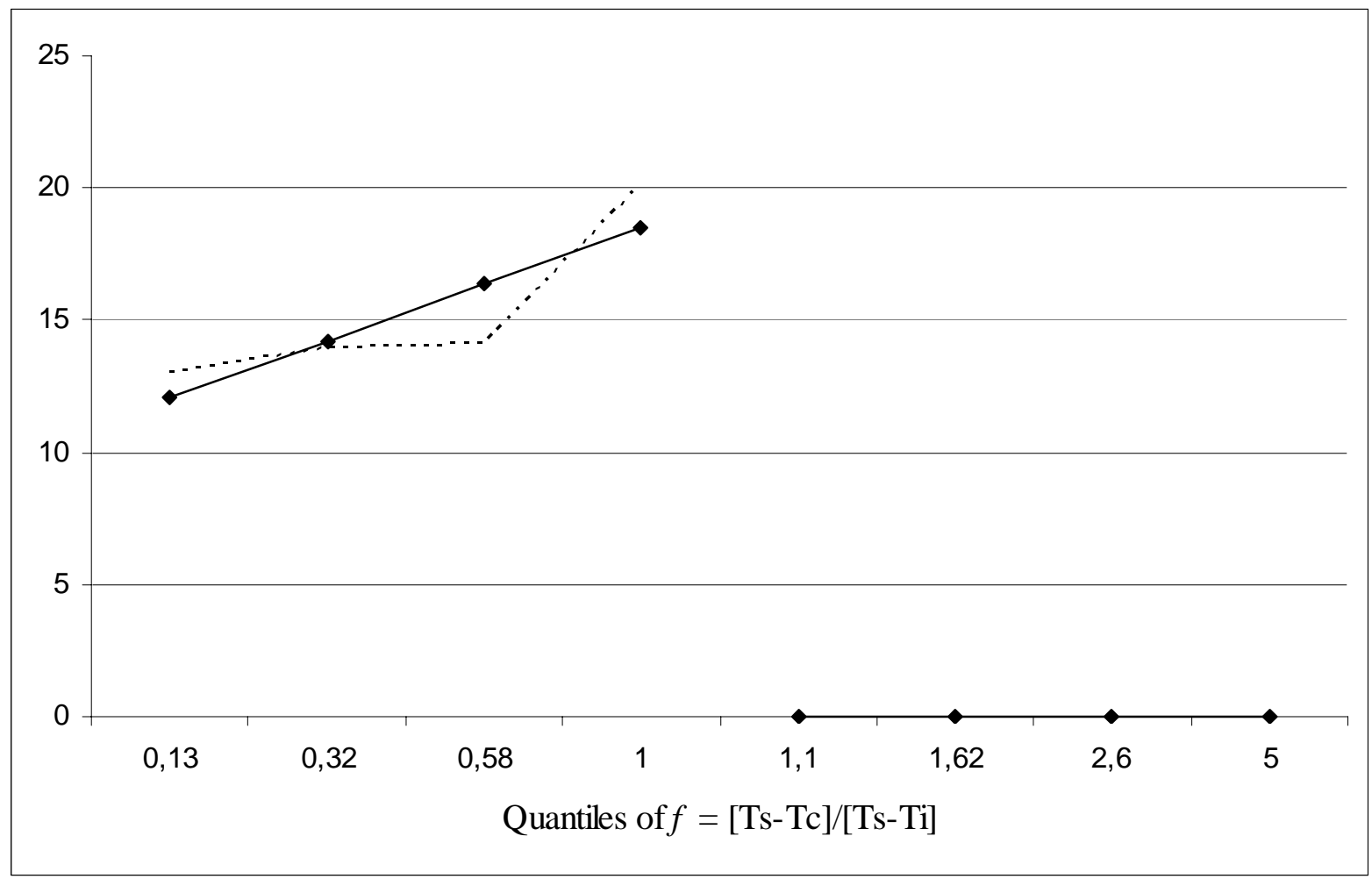

Sample: Male, prospective date of release $t_{s}$ comprised between Nov. 1996 and Jan. 2007.

Figure 4b: Original Sentence (in log) as a Function of the Residual Sentence Ratio.

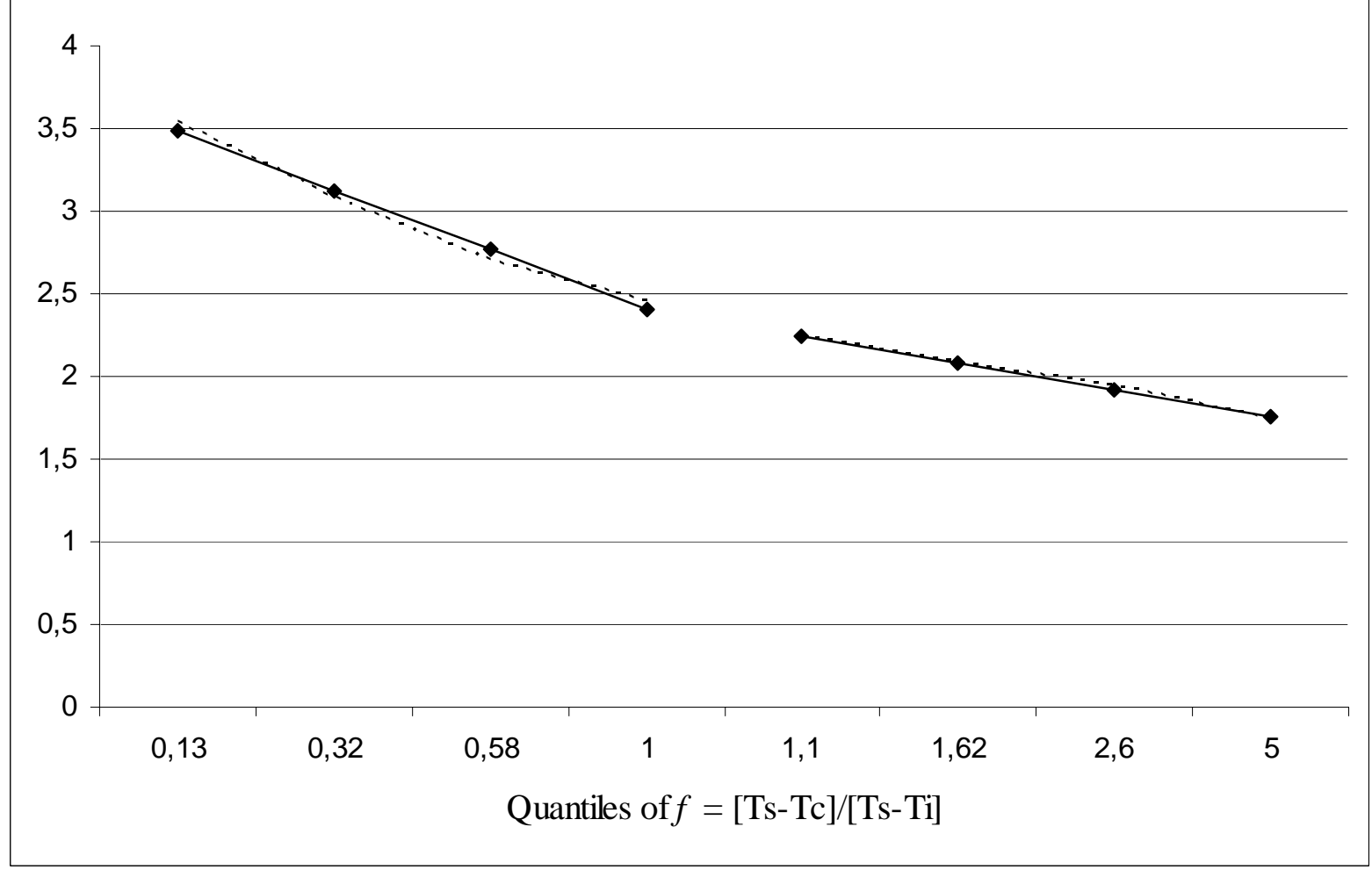

Sample: Male, prospective date of release $t_{s}$ comprised between Nov. 1996 and Jan. 2007. 
Figure 4c: Recidivism Rate as a Function of the Residual Sentence Ratio $f$.

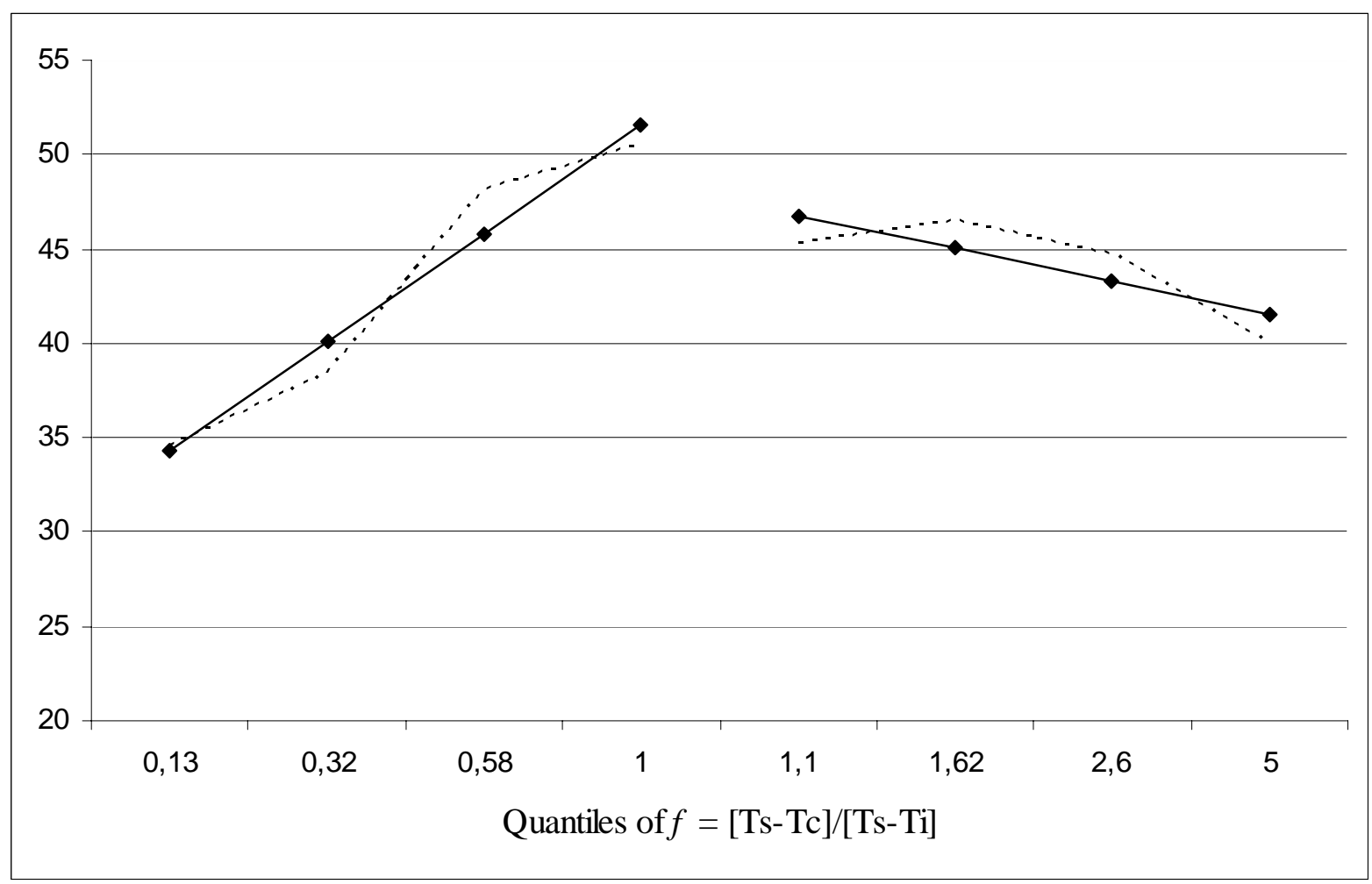

Sample: Male, prospective date of release $t_{s}$ comprised between Nov. 1996 and Jan. 2007. 
Table 1: The Effect of the Pardon on Recidivism: Estimates Using the Discontinuity in Relationship Between Presidential Pardon and Prospective Date of Release.

\begin{tabular}{|c|c|c|c|c|c|c|}
\hline \multirow{2}{*}{$\begin{array}{l}\text { Panel A: } \\
\text { (Full } \\
\text { Sample) }\end{array}$} & Pardon & Collective & Original & & Recidivism & \\
\hline & (1) & (2) & (3) & $\begin{array}{c}\text { Reduced } \\
\text { form } \\
(4)\end{array}$ & $\begin{array}{l}\text { OLS } \\
(5) \\
\end{array}$ & $\begin{array}{l}\text { IV } \\
\text { (6) } \\
\end{array}$ \\
\hline Pardon & - & - & - & - & $\begin{array}{l}.070 * \\
(.024)\end{array}$ & $\begin{array}{l}.186^{*} \\
(.075)\end{array}$ \\
\hline$\left(t_{s}>t_{c}\right)$ & $\begin{array}{l}.672 * \\
(.038)\end{array}$ & $\begin{array}{l}.127 * \\
(.016)\end{array}$ & $\begin{array}{c}74.5 \\
(105.7)\end{array}$ & $\begin{array}{l}.125^{*} \\
(.050)\end{array}$ & - & - \\
\hline $\begin{array}{l}\left(t_{s}-t_{c}\right) \times \\
\left(t_{s}>t_{c}\right) \\
t_{s}\end{array}$ & $\begin{array}{c}-.0014 \\
(.0009) \\
-.0004 \\
(.0009)\end{array}$ & $\begin{array}{c}-.00024 \\
(.00036) \\
-.00005 \\
(.00036)\end{array}$ & $\begin{array}{l}2.43 \\
(2.35) \\
-2.56 \\
(2.34)\end{array}$ & $\begin{array}{c}.0010 \\
(.0011) \\
-.0013 \\
(.0011)\end{array}$ & $\begin{array}{c}.0009 \\
(.0008) \\
-.0008 \\
(.0008)\end{array}$ & $\begin{array}{l}.0023 \\
(.0012) \\
-.0021 \\
(.0011)\end{array}$ \\
\hline $\begin{array}{l}\text { Original } \\
\text { sentence }\end{array}$ & yes & yes & no & yes & yes & yes \\
\hline Nb Obs. & 2605 & 2605 & 2605 & 2605 & 2605 & 2605 \\
\hline \multirow{2}{*}{$\begin{array}{l}\text { Panel B: } \\
\text { (Restricted } \\
\text { Sample) }\end{array}$} & Pardon & $\begin{array}{l}\text { Collective } \\
\text { Remission }\end{array}$ & $\begin{array}{l}\text { Original } \\
\text { Sentence }\end{array}$ & & Recidivism & \\
\hline & (1) & (2) & (3) & $\begin{array}{c}\text { Reduced } \\
\text { form } \\
(4)\end{array}$ & $\begin{array}{l}\text { OLS } \\
(5) \\
\end{array}$ & $\begin{array}{l}\text { IV } \\
\text { (5) } \\
\end{array}$ \\
\hline Pardon & - & - & & - & $\begin{array}{l}.123 * \\
(.043)\end{array}$ & $\begin{array}{l}.183^{*} \\
(.092)\end{array}$ \\
\hline$\left(t_{s}>t_{c}\right)$ & $\begin{array}{l}.723^{*} \\
(.045)\end{array}$ & $\begin{array}{l}.060 * \\
(.014)\end{array}$ & $\begin{array}{c}14.7 \\
(142.8)\end{array}$ & $\begin{array}{l}.132 * \\
(.066)\end{array}$ & - & - \\
\hline $\begin{array}{l}\left(t_{s}-t_{c}\right) \mathrm{x} \\
\left(t_{s}>t_{c}\right) \\
t_{s}\end{array}$ & $\begin{array}{l}-.0027 \\
(.0012) \\
-.00017 \\
(.00078)\end{array}$ & $\begin{array}{c}.00098 \\
(.00037) \\
.00008 \\
(.00024)\end{array}$ & $\begin{array}{l}4.1 \\
(3.6) \\
-2.6 \\
(2.4)\end{array}$ & $\begin{array}{c}.0022 \\
(.0017) \\
-.0023 \\
(.0011)\end{array}$ & $\begin{array}{c}.0026 \\
(.0017) \\
-.0018 \\
(.0009)\end{array}$ & $\begin{array}{l}.0027 \\
(.0017) \\
-.0022 \\
(.0011)\end{array}$ \\
\hline $\begin{array}{l}\text { Original } \\
\text { sentence }\end{array}$ & yes & yes & no & yes & yes & yes \\
\hline Nb Obs. & 894 & 894 & 894 & 894 & 894 & 894 \\
\hline
\end{tabular}

Full Sample (Panel A) : Male, prospective date of release $t_{s}$ between May 1996 and May 1997.

Restricted Sample (Panel B) : Male, prospective date of release $t_{s}$ between May and September 1996.

All regressions include a full set of (thirteen) dummies indicating the number of months of imprisonment $\left(D_{m}\right)$ the individuals have been sentenced to. Standard errors are in parenthesis and * indicates coefficients which are significant at the $5 \%$ level. 
Table 2: The Effect of Collective Remission Rate on Recidivism: Estimates Using the Discontinuity in Relationship Between Presidential Pardon and Prospective Date of Release.

Collective

remission rate

(1)

$(-)$

remission rate

\section{Recidivism}

\begin{tabular}{cl}
$\begin{array}{c}\text { Reduced-form } \\
(2)\end{array}$ & IV \\
\hline
\end{tabular}

$.98 *$

$(.41)$

$(-)$

$(.050)$

.0010

.0023

(.0011)

$-.0013$

(.0011)

yes

yes

Original

yes

2605

2605

Sample: Male, prospective date of release $t_{s}$ between May 1996 and May 1997.

All regressions include a full set of (thirteen) dummies indicating the number of months of imprisonment $\left(D_{m}\right)$ the individuals have been sentenced to. Standard errors are in parenthesis and * indicates coefficients which are significant at the $5 \%$ level. 
Table 3: Effect of Collective Remissions on Recidivism: an Evaluation using the Relationship Between Collective Remissions and Fraction of the Sentence that remained to be spent in Prison by 1996, July the $9^{\text {th }}$.

\begin{tabular}{|c|c|c|c|c|}
\hline & Collective & & Recidivism & \\
\hline & (1) & $\begin{array}{l}\text { Reduced- } \\
\text { form } \\
(2)\end{array}$ & $\begin{array}{l}\text { IV } \\
\text { (3) } \\
\end{array}$ & $\begin{array}{l}\text { IV } \\
(4) \\
\end{array}$ \\
\hline $\begin{array}{l}\text { Collective } \\
\text { Remission } \\
\text { rate }(C)\end{array}$ & $(-)$ & $(-)$ & $\begin{array}{l}.827^{*} \\
(.37)\end{array}$ & $\begin{array}{l}.77^{*} \\
(.38)\end{array}$ \\
\hline $\begin{array}{l}\text { Remaining } \\
\text { sentence by } \\
t_{c} \\
F \mathrm{x}(F<1))\end{array}$ & $\begin{array}{l}.146 * \\
(.019)\end{array}$ & $\begin{array}{l}.121 * \\
(.056)\end{array}$ & $(-)$ & $(-)$ \\
\hline $\begin{array}{l}\text { Incarceration } \\
\text { after } t_{c}(F \geq 1)\end{array}$ & $\begin{array}{l}-.0496 * \\
(.0121)\end{array}$ & $\begin{array}{l}-.059 \\
(.035)\end{array}$ & $\begin{array}{l}-.0174 \\
(.0264)\end{array}$ & $(-)$ \\
\hline$F$ & $\begin{array}{c}.0004 \\
(.0006)\end{array}$ & $\begin{array}{c}.00002 \\
(.00173)\end{array}$ & $\begin{array}{c}-.00034 \\
(.00181)\end{array}$ & $\begin{array}{c}.00002 \\
(.00173)\end{array}$ \\
\hline $\begin{array}{l}\text { Prospective } \\
\text { date of release } \\
\left(t_{s}\right)\end{array}$ & $\begin{array}{c}-.00029 \\
(.00005)\end{array}$ & $\begin{array}{c}-.000199 \\
(.000133)\end{array}$ & $\begin{array}{c}.000044 \\
(.000152)\end{array}$ & $\begin{array}{c}.00007 \\
(.00014)\end{array}$ \\
\hline $\begin{array}{l}F \text {-test : } \\
F \times(F<1)= \\
(F \geq 1)=0\end{array}$ & $\begin{array}{c}29.9 * \\
(<.001)\end{array}$ & - & - & - \\
\hline Nb Obs. & 2150 & 2150 & 2150 & 2150 \\
\hline
\end{tabular}

Sample: Inmates released after the 1996, July, $9^{\text {th }}$, cut-off. 
Appendix

Table A1: Basic Sample Description

\begin{tabular}{lcc}
\hline \hline & Mean & Std \\
Recidivism & .453 & .010 \\
Presidential Pardon & .473 & .010 \\
Original Sentence (days) & 541.0 & 19.9 \\
Collective remission rate & .112 & .003 \\
Overall remission rate & .324 & .007 \\
Release after Bastille Day & .826 & .007 \\
Non French & .302 & .009 \\
Age at release (years) & 31.8 & .20 \\
Homeless & .170 & .007 \\
Married & .839 & .007 \\
Nb. Obs. & 2605 & 2605 \\
\hline \hline Sampl: Male, prosec
\end{tabular}

Sample: Male, prospective date of release $t_{s}$ between May 1996 and May 1997, $(\mathrm{N}=2605)$. 
Table A2: The Discontinuity in Individual Characteristics and Crime Characteristics at the $9^{\text {th }}$ of July cut-off.

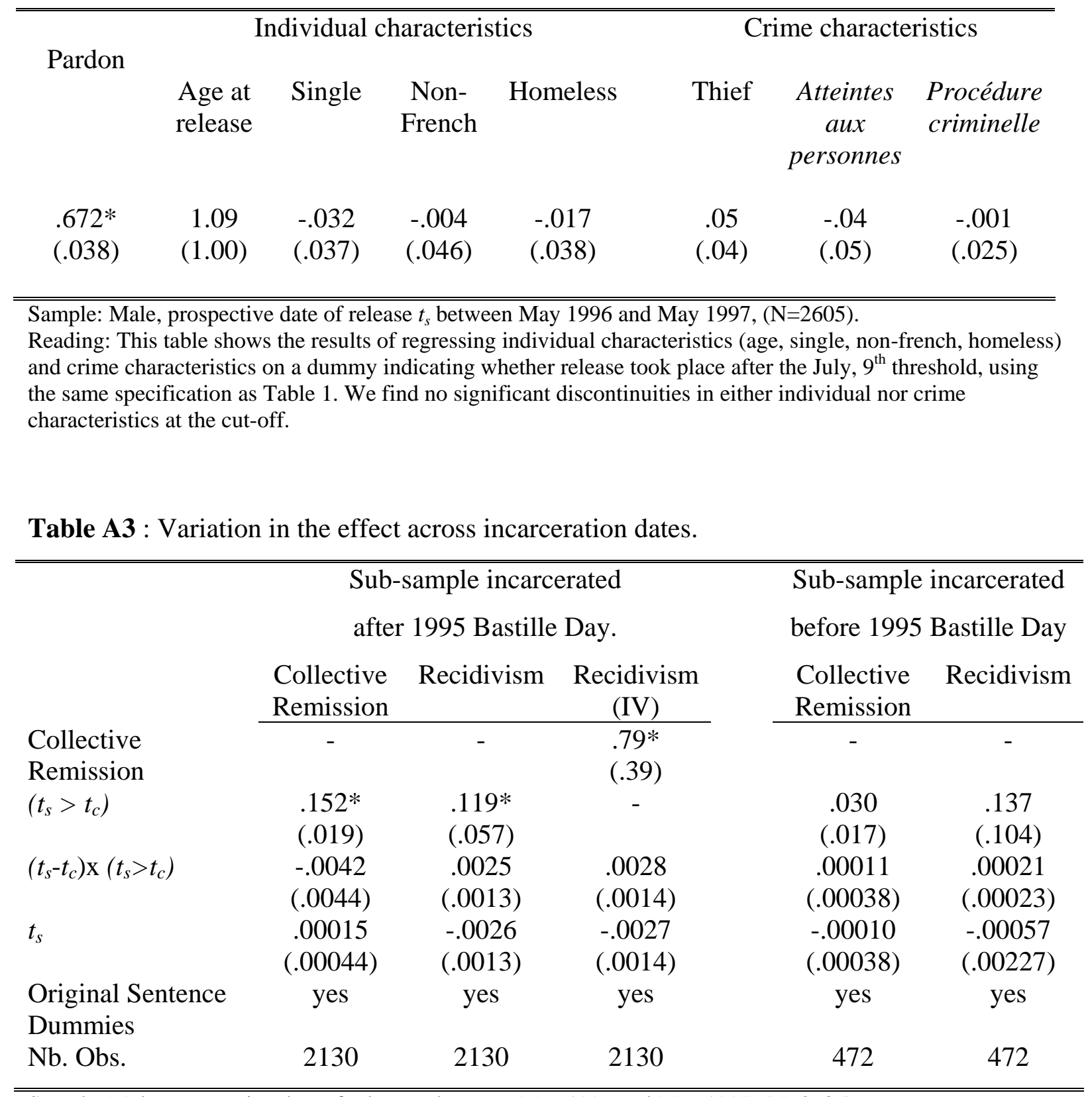

Sample: Male, prospective date of release $t_{s}$ between May 1996 and May 1997, (N=2605). 


\section{DECRET DE GRACES COLLECTIVES}

Le Président de la République ;

Vu la Constitution du 4 octobre 1958 ;

Vu les articles R 133-1 et R 133-2 du Code Pénal ;

\section{E C R E T E}

ARTICLE 1ER, - $\quad$ Les condamnés détenus à la date du 9 juillet 1996 en exécution d'une ou plusieurs peines privatives de liberté à temps bénéficient :

- d'une remise gracieuse de sept jours lorsque la durée de la détention restant à subir n'excède pas un mois ;

- dans les autres cas, d'une remise gracieuse de sept jours par mois de détention restant à subir, augmentée, le cas échéant, de sept jours pour la part supplémentaire inférieure à un mois, sans que la durée totale de la remise puisse excéder quatre mois.

Les dispositions de l'alinéa qui précède sont également applicables aux personnes condamnées au plus tard le 9 juillet 1996 et détenues à cette même date en vertu d'une décision de placement ou de maintien en détention prononcée par la juridiction de jugement, sous réserve que la peine devienne exécutoire avant le 21 juillet 1996.

ARTICLE 2. - Sont exclus du bénéfice de l'article ler les condamnés détenus pour l'exécution d'une ou plusieurs peines dont l'une au moins a été prononcée pour :

toute infraction entrant dans le champ d'application de l'article 706-16 du code de procédure pénale, même lorsque les faits sont antérieurs à l'entrée en vigueur de la loi n ${ }^{\circ} 86-1020 \mathrm{du}$ 9 septembre 1986 relative à la lutte contre le terrorisme ;

toute infraction prévue au chapitre ler du Titre II du Livre III du code pénal dans sa rédaction antérieure au ler mars 1994 ou au Titre II du Livre II du code pénal, et qualifiée crime lorsqu'elle a été commise sur la personne d'un mineur de moins de 15 ans ;

les infractions de production ou fabrication de substances ou plantes vénéneuses classées comme stupéfiants, d'importation, d'exportation ou de contrebande desdites substances ou plantes ou d'association formée ou entente établie en vue de commettre ces infractions, ou pour toute infraction prévue au troisième alinéa de l'article L.627 du code de la santé publique dans sa rédaction antérieure à la loi n ${ }^{\circ}$ 92-1336 du 16 décembre 1992 ou à l'article 222-38 alinéa 1 du code pénal lorsque la peine prononcée est égale ou supérieure à 3 ans d'emprisonnement sans sursis ; 
toute infraction définie par les articles 295 à 298, 301, 303, 304 et 309 à 311 du code pénal dans leur rédaction en vigueur avant le ler mars 1994 et par les articles $221-4$ alinéa $14^{\circ}$, 221-5 alinéa $3,222-3$ alinéa $14^{\circ}, 222-8$ alinéa $14^{\circ}, 222-10$ alinéa $1-4^{\circ}, 222-12$ alinéa 1$4^{\circ}$ et $222-13$ alinéa $1-4^{\circ}$ du code pénal lorsqu'elle a été commise envers un agent de l'administration pénitentiaire ou de la force publique dans l'exercice ou à l'occasion de l'exercice de ses fonctions ;

toute infraction définie par les articles $175,175-1,177$ et 178 du code pénal dans leur rédaction en vigueur avant le ler mars 1994 et par les articles 432-11, 432-12, 432-13, 4331, 433-2 et 441-8 du code pénal et L.152-6 du code du travail.

d'évasion.

Sont également exclus du bénéfice de l'article 1er les détenus en état

ARTICLE 3. =

ARTICLE 4. -

Fait à PARIS, le 4 juillet 1996 décret.
Les personnes condamnées au plus tard le 9 juillet 1996 à une peine temporaire privative de liberté non ramenée à exécution à cette même date, hors le cas prévu par le deuxième alinéa de l'article ler, bénéficient d'une remise gracieuse de 2 mois, sous réserve que la peine soit devenue exécutoire avant le 21 juillet 1996.

Toutefois, la remise gracieuse ne s'applique pas aux peines prononcées pour les infractions mentionnées au premier alinéa de l'article 2 du présent

Le garde des sceaux, ministre de la justice, et le ministre de la défense sont chargés, chacun en ce qui le concerne, de l'exécution du présent décret qui prendra effet le 10 juillet 1996.

Jacques CHIRAC

Par le Président de la République :

Le Premier ministre

Alain JUPPE

Le garde des sceaux, ministre de la justice

Jacques TOUBON

Le ministre de la défense 